\title{
External Quality Assurance Project Report for the National Atmospheric Deposition Program's National Trends Network and Mercury Deposition Network, 2013-14
}

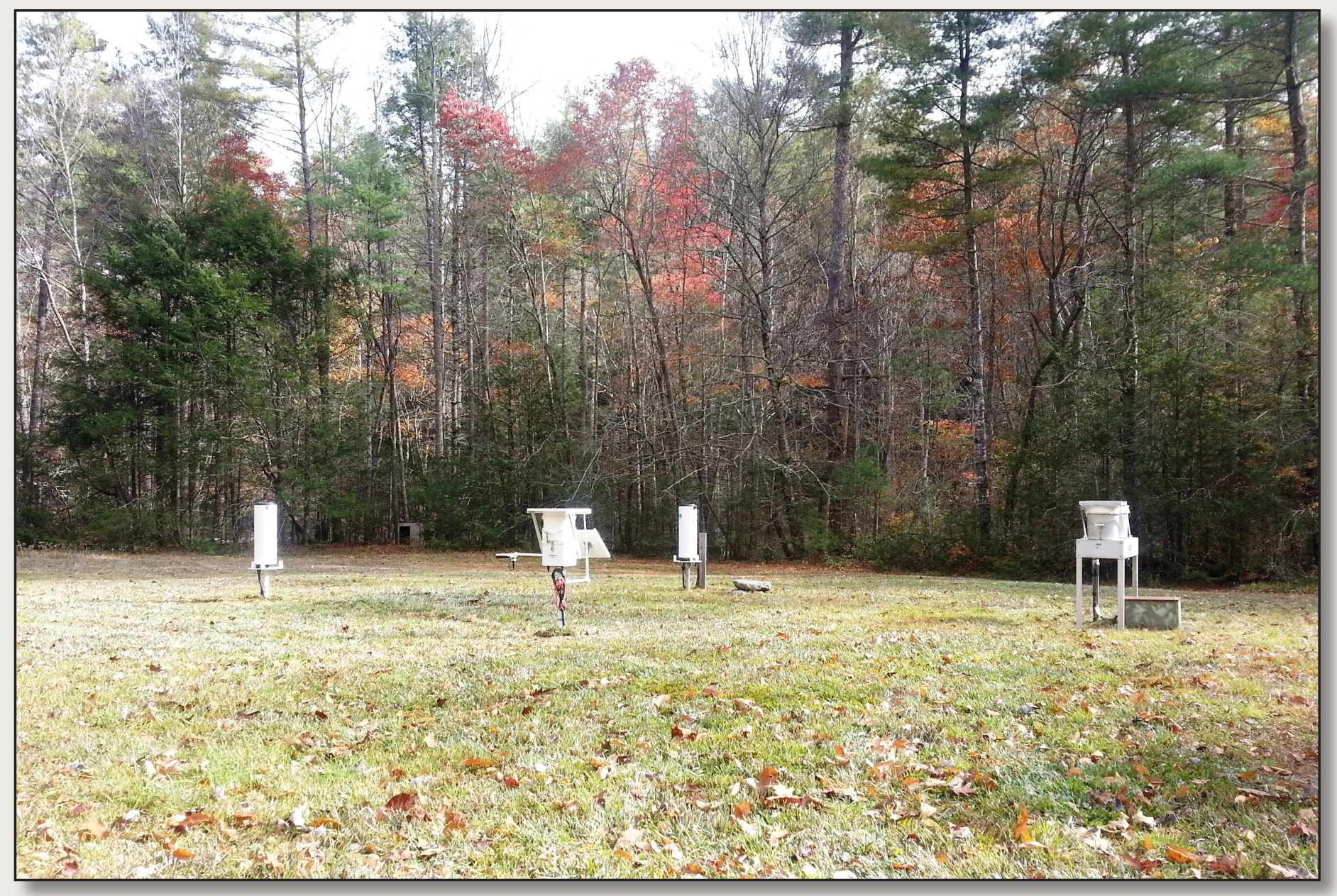

Scientific Investigations Report 2016-5069 
Cover. Colocated National Atmospheric Deposition Program's National Trends Network sites TN11 and 11TN, Great Smoky Mountains National Park, near Gatlinburg, Tennessee. Photograph by Eric Hebert, Environmental Engineering and Measurement Services, Inc. 


\section{External Quality Assurance Project Report for the National Atmospheric Deposition Program's National Trends Network and Mercury Deposition Network, 2013-14}

By Gregory A. Wetherbee and RoseAnn Martin

Scientific Investigations Report 2016-5069 


\title{
U.S. Department of the Interior SALLY JEWELL, Secretary
}

\section{U.S. Geological Survey Suzette M. Kimball, Director}

\author{
U.S. Geological Survey, Reston, Virginia: 2016
}

For more information on the USGS - the Federal source for science about the Earth, its natural and living resources, natural hazards, and the environment—visit http://www.usgs.gov or call 1-888-ASK-USGS.

For an overview of USGS information products, including maps, imagery, and publications, visit http://store.usgs.gov.

Any use of trade, firm, or product names is for descriptive purposes only and does not imply endorsement by the U.S. Government.

Although this information product, for the most part, is in the public domain, it also may contain copyrighted materials as noted in the text. Permission to reproduce copyrighted items must be secured from the copyright owner.

Suggested citation:

Wetherbee, G.A., and Martin, RoseAnn, 2016, External quality assurance project report for the National Atmospheric Deposition Program's National Trends Network and Mercury Deposition Network, 2013-14: U.S. Geological Survey Scientific Investigations Report 2016-5069, 22 p., http://dx.doi.org/10.3133/sir20165069.

ISSN 2328-0328 (online) 


\section{Contents}

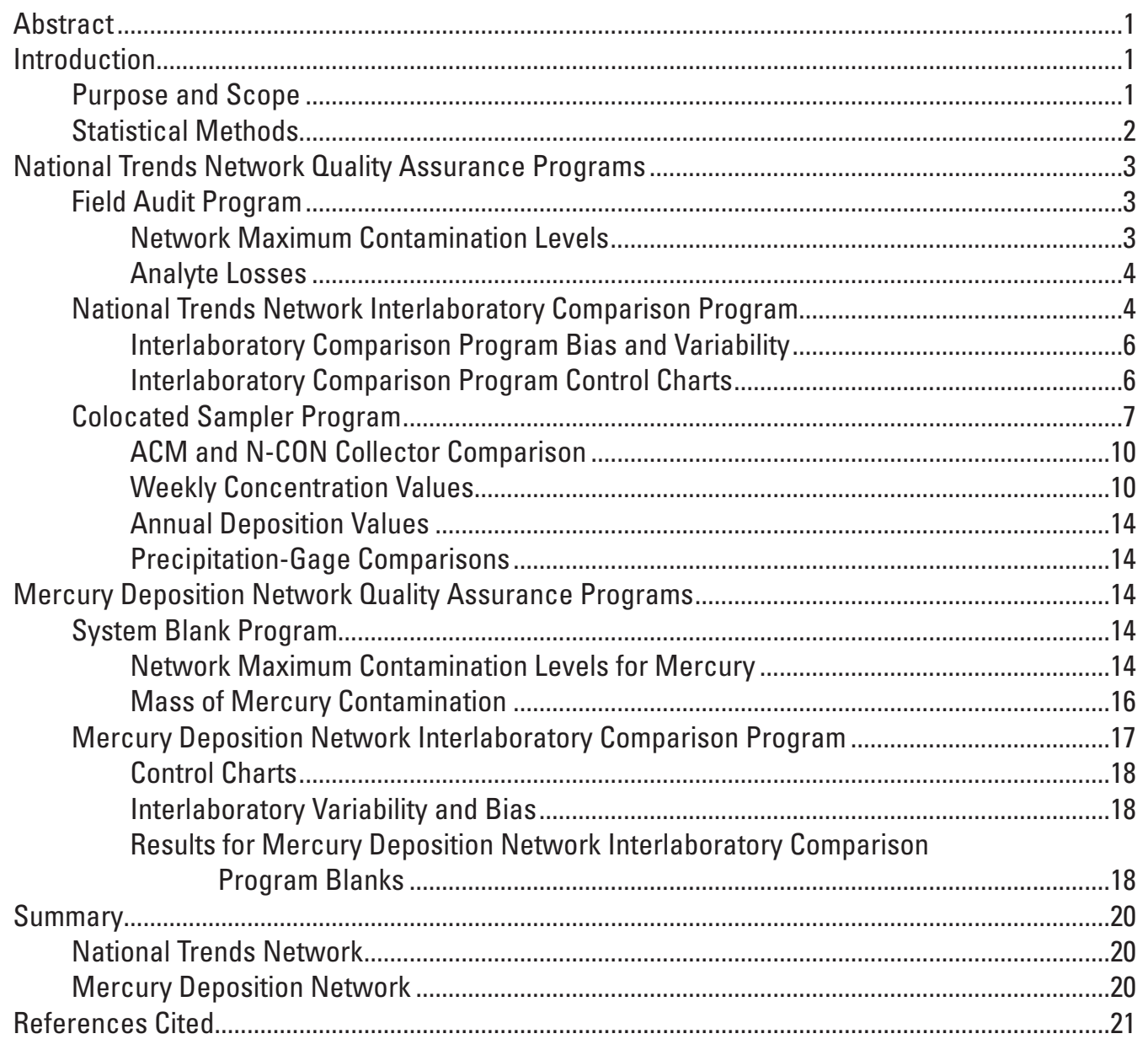

\section{Figures}

1. Network maximum contamination levels for National Trends Network analytes calculated by 3-year moving intervals, 1997-2014

2. Maximum loss of hydrogen ion, ammonium, and nitrate from weekly National Trends Network samples calculated by 3-year moving intervals, 1997-2014.

3. Differences between concentration values reported by the CAL and the median concentration values for all participating laboratories in the interlaboratory comparison program for the National Trends Network, 2013-14, calculated by solution for $(A)$ calcium, magnesium, sodium, potassium, ammonium, chloride, nitrate, and sulfate and $(B)$ bromide and hydrogen-ion concentrations and specific conductance

4. Daily precipitation depths and calculated median absolute percent differences for $(A)$ colocated ETI Noah IV precipitation gages, sites C013 and 13C0, C098 and C089, and TN11 and 11TN and (B) colocated OTT Pluvio-2 precipitation gages, sites $\mathrm{CO} 00$ and $00 \mathrm{CO}$ and KS32 and 32KS, water years 2013-14

5. Differences between total mercury concentrations reported by the HAL and the median concentration values for all participating laboratories in the interlaboratory comparison program for the Mercury Deposition Network, 2013-14. 


\section{Tables}

1. National Atmospheric Deposition Program's National Trends Network method detection limits, network maximum contamination levels, and analyte losses calculated from field audit samples in addition to calculated concentration quartiles for all valid monitoring data, 2012-14.

2. Analyte most probable values for synthetic precipitation solutions used in the 2013-14 National Trends Network interlaboratory comparison program

3. Median differences between reported concentrations and most probable values for synthetic wet-deposition samples, 2013 interlaboratory comparison program...............8

4. Median differences between reported concentrations and most probable values for synthetic wet-deposition samples, 2014 interlaboratory comparison program.

5. Number of analyte determinations greater than the method detection limits by participating laboratory and by analyte for de-ionized water samples, 2013-14 10

6. Field instrumentation, colocated National Trends Network sites, 2013-14

7. Median weekly N-CON Systems Company, Inc.-minus-Aerochem Metrics parameter differences and annual deposition differences, water year 2013

8. Median weekly N-CON Systems Company, Inc.-minus-Aerochem Metrics parameter differences and annual deposition differences, water year 2014

9. Three-year moving network maximum contamination levels and 90-percent upper confidence limits on 50th, 75th, and 90th percentiles of mercury contamination mass in system blank samples, 2004-14.

10. Most probable values for solutions used during 2013-14 for the Mercury Deposition Network interlaboratory comparison program

11. Differences between reported concentrations and most probable values for total mercury determinations, Mercury Deposition Network interlaboratory comparison program, 2013-14

12. Number of total mercury determinations greater than the method detection limits by participating laboratory for blank samples, Mercury Deposition Network interlaboratory comparison program, 2013-14...

\section{Conversion Factors}

International System of Units to Inch/Pound

\begin{tabular}{lcl}
\hline \multicolumn{1}{c}{ Multiply } & By & To obtain \\
\hline & Length & \\
\hline centimeter $(\mathrm{cm})$ & 0.3937 & Volume \\
\hline & 1.057 & \\
\hline liter $(\mathrm{L})$ & 0.03381 & quart $(\mathrm{qt})$ \\
milliliter $(\mathrm{mL})$ & Application rate & ounce, fluid $(\mathrm{oz})$ \\
\hline & 0.8264 & pound per acre $(\mathrm{lb} / \mathrm{acre})$ \\
\hline kilogram per hectare $(\mathrm{kg} / \mathrm{ha})$ & Concentration & \\
\hline & $3.34 \times 10^{-5}$ & ounce per quart $(\mathrm{oz} / \mathrm{qt})$ \\
milligram per liter $(\mathrm{mg} / \mathrm{L})$ & $3.34 \times 10^{-11}$ & ounce per quart $(\mathrm{oz} / \mathrm{qt})$ \\
nanogram per liter $(\mathrm{ng} / \mathrm{L})$ & $3.34 \times 10^{-8}$ & ounce per quart $(\mathrm{oz} / \mathrm{qt})$ \\
microgram per liter $(\mu \mathrm{g} / \mathrm{L})$ &
\end{tabular}

Temperature in degrees Celsius $\left({ }^{\circ} \mathrm{C}\right)$ may be converted to degrees Fahrenheit $\left({ }^{\circ} \mathrm{F}\right)$ as follows: ${ }^{\circ} \mathrm{F}=\left(1.8 \times{ }^{\circ} \mathrm{C}\right)+32$.

Temperature in degrees Fahrenheit $\left({ }^{\circ} \mathrm{F}\right)$ may be converted to degrees Celsius $\left({ }^{\circ} \mathrm{C}\right)$ as follows: ${ }^{\circ} \mathrm{C}=\left({ }^{\circ} \mathrm{F}-32\right) / 1.8$. 


\section{Supplemental Information}

Specific conductance is given in microsiemens per centimeter at 25 degrees Celsius $(\mu \mathrm{S} / \mathrm{cm}$ at $\left.25^{\circ} \mathrm{C}\right)$.

Concentrations of chemical constituents in water are given in either milligrams per liter (mg/L), micrograms per liter $(\mu \mathrm{g} / \mathrm{L}$ ) or nanograms per liter $(\mathrm{ng} / \mathrm{L})$.

$\alpha$, alpha, is the maximum probability of incorrect rejection of the null hypothesis.

$100(p)$ th is the percentile equal to 100 times a value of $p$, for example, $100 \times(.9)=90$ th percentile.

Absolute value of $x=|x|$, where $x$ takes the form of numerical values or algebraic expressions.

Study period, calendar year or water years 2013-14, depending on the program.

Water year (WY) is the 12-month period from October 1 through September 30 of the following year and is designated by the calendar year in which it ends.

\section{Abbreviations}

$\begin{array}{ll}\text { ACM } & \text { AeroChem Metrics } \\ \text { ACAP } & \text { Asia Center for Air Pollution Research } \\ \text { AIRMoN } & \text { Atmospheric Integrated Research Monitoring Network } \\ \text { AMEC } & \text { AMEC Foster Wheeler for 2014, formerly AMEC, Inc. in 2013 } \\ \text { BOS } & \text { Branch of Quality Systems } \\ \text { CAL } & \text { Central Analytical Laboratory, Illinois State Water Survey } \\ \text { CASIG } & \text { Chinese Academy of Sciences, Institute of Geochemistry (People's Republic } \\ & \text { of China) } \\ \text { CIES } & \text { Carey Institute of Ecosystem Studies } \\ \text { CVAFS } & \text { Cold vapor atomic fluorescence spectroscopy } \\ \text { DASNCU } & \text { Department of Atmospheric Sciences, National Central University (Taiwan) } \\ \text { EPA } & \text { U.S. Environmental Protection Agency } \\ \text { ECST } & \text { Environment and Climate Change Canada (formerly [2013-14] Environment } \\ \text { ETI Noah IV } & \text { Canada) Science and Technology Branch } \\ f-p s i g & \text { Environmental Technologies, Inc. Noah IV precipitation gage } \\ \text { FRL } & \text { F-pseudosigma } \\ \text { GAPMN } & \text { Gett Research, Limited (Canada) } \\ \text { GMOS } & \text { Agency [Umweltbundesamt] } \\ \text { HAL } & \text { Global Mercury Observation System } \\ \text { HCI } & \text { Mercury Analytical Laboratory, Eurofins Frontier Global Sciences, Inc. } \\ \text { Hg } & \text { hydrochloric acid } \\ \text { ISWS } & \text { mercury } \\ \text { IVL } & \text { Illinois State Water Survey } \\ \text { JSIPS } & \text { IVL Swedish Environmental Research Institute (Sweden) } \\ \text { LEEO } & \text { Jozef Stefan International Postgraduate School (Slovenia) } \\ \text { MDL } & \text { Quebec Laboratory for Environmental Testing (Canada), also known as OLET } \\ \text { MDN } & \text { method detection limit } \\ \text { MeHg } & \text { Mercury Deposition Network } \\ & \text { methylmercury } \\ & \\ & \end{array}$




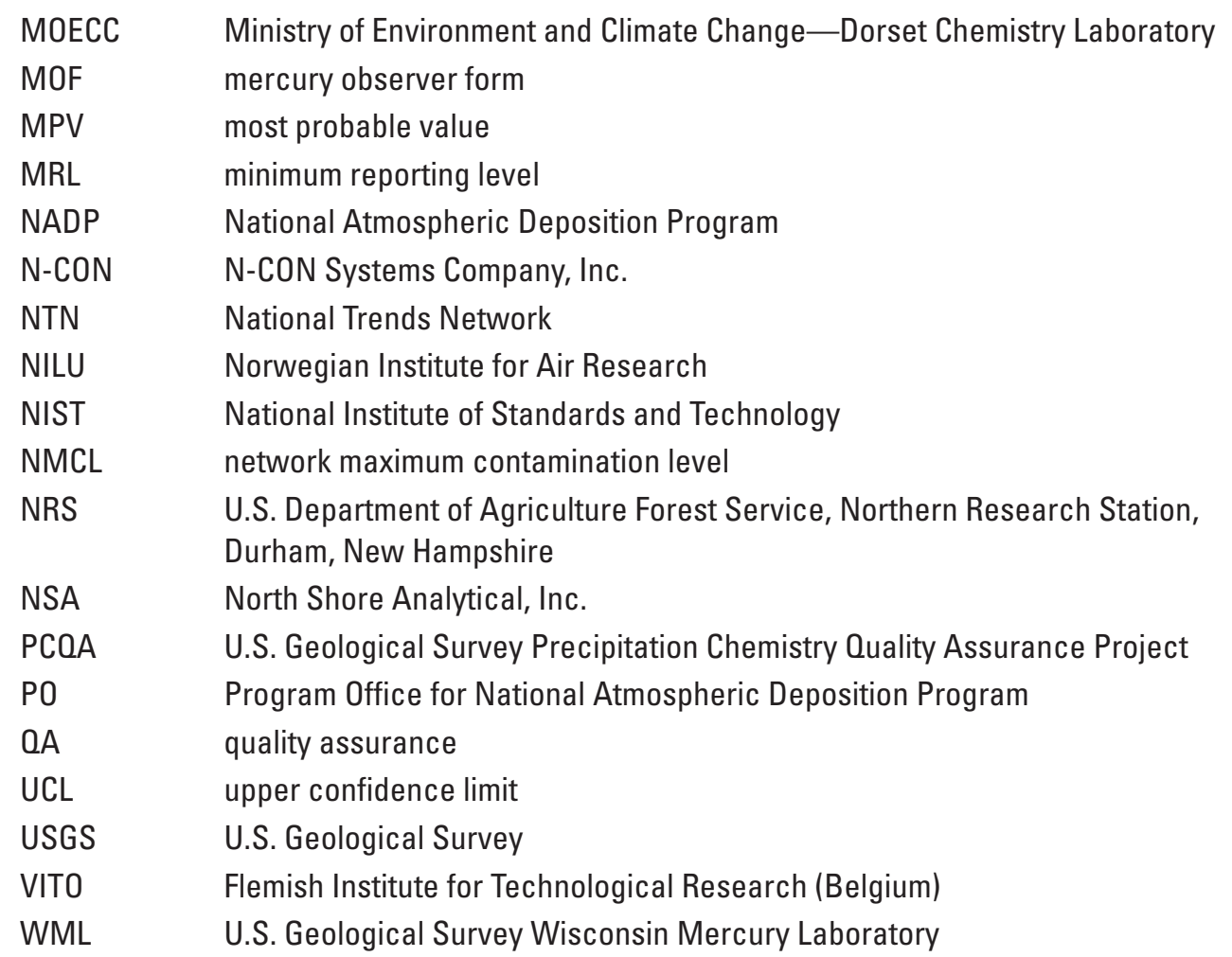




\title{
External Quality Assurance Project Report for the National Atmospheric Deposition Program's National Trends Network and Mercury Deposition Network, 2013-14
}

\author{
By Gregory A. Wetherbee and RoseAnn Martin
}

\section{Abstract}

The U.S. Geological Survey Branch of Quality Systems operated five distinct programs to provide external quality assurance monitoring for the National Atmospheric Deposition Program's (NADP) National Trends Network and Mercury Deposition Network during 2013-14. The National Trends Network programs include (1) a field audit program to evaluate sample contamination and stability, (2) an interlaboratory comparison program to evaluate analytical laboratory performance, and (3) a colocated sampler program to evaluate bias from precipitation sampler upgrades. The Mercury Deposition Network programs include the (4) system blank program and (5) an interlaboratory comparison program. The results indicate that NADP data continue to be of sufficient quality for the analysis of spatial distributions and time trends for chemical constituents in wet deposition.

The field audit program results indicate that sample contamination levels for calcium, nitrate, and sulfate continued to increase during the study period while sodium and chloride contamination decreased and magnesium, potassium, ammonium, and hydrogen-ion contamination have remained relatively constant. Analyte losses due to potential sample instability were negligible. The NADP Central Analytical Laboratory produced interlaboratory comparison results with low bias and variability compared to other domestic and international laboratories that support atmospheric deposition monitoring.

Colocated sampler program results from dissimilar colocated collectors suggest that the retrofit of the National Trends Network with N-CON Systems precipitation collectors could cause shifts in NADP annual deposition (concentration multiplied by depth) values from +6.2 to +51 percent for ammonium, from +8.1 to +61 percent for nitrate, from 3.8 to 71 percent for sulfate, from -24 to +15 percent for hydrogenion deposition, and larger shifts (from -14 to +102 percent) for calcium, magnesium, sodium, potassium, and chloride. The N-CON Systems collector typically catches more precipitation than the NADP-approved Aerochem Metrics Model 301 collector, but it typically caught slightly less precipitation than the Aerochem Metrics collector at a wind-swept, high-altitude site during water year 2013.
Paired, identical OTT Pluvio-2 and ETI Noah IV rain gages were operated at the same sites. Results of the colocated rain gages indicate from 0 to 3.7 percent median absolute percent difference for weekly precipitation-depth measurements and from 0.05 to 5.6 absolute percent difference for annual total precipitation depth.

The Mercury Deposition Network programs include the system blank program and an interlaboratory comparison program. System blank results indicated that maximum total mercury contamination concentrations in samples were less than the third percentile of all Mercury Deposition Network sample concentrations. The Mercury Analytical Laboratory produced chemical concentration results with low bias and variability compared with other domestic and international laboratories that support atmospheric-deposition monitoring.

\section{Introduction}

Quality assurance (QA) results in this report allow investigators to differentiate between true environmental signals and the variability and bias introduced by sample collection, processing, and laboratory analysis for the National Atmospheric Deposition Program (NADP) data. The U.S. Geological Survey (USGS) Precipitation Chemistry Quality Assurance project (PCQA) ensures that NADP provides data users with long-term, known-quality atmospheric wet-deposition information. The project is administered by the USGS Office of Water Quality, Branch of Quality Systems in Denver, Colorado.

\section{Purpose and Scope}

The NADP includes three wet-deposition monitoring networks: (1) the National Trends Network (NTN), (2) the Mercury Deposition Network (MDN), and (3) the Atmospheric Integrated Research Monitoring Network (AIRMoN). This report updates the independent assessment of NADP data quality using PCQA results obtained for calendar years and water years 2013-14 (study period) for the NTN and MDN. Results obtained in previous years are used for comparison. The AIRMoN data are not specifically addressed herein, but the AIRMoN uses NTN monitoring protocols to collect event-based samples. 
The field audit program and the system blank program assessed the effects of onsite exposure, sample handling, and shipping on the chemistry of NTN and MDN samples, respectively. Two interlaboratory comparison programs assessed the bias and variability of chemical analysis data from the Central Analytical Laboratory (CAL) at Illinois State Water Survey, Champaign, Ill. and the Mercury Analytical Laboratory (HAL) at Eurofins Frontier Global Sciences, Inc., Bothell, Wash. Potential shifts in NTN data resulting from the replacement of original network instrumentation with new electronic recording precipitation gages and sample collectors that use optical precipitation sensors were also quantified using a colocated sampler program. Detailed information on USGS QA procedures and analytical methods for the NTN and MDN is available in Latysh and Wetherbee $(2005,2007)$.

Most of the PCQA programs are operated on a calendaryear basis, but the colocated sampler program is operated on a water-year basis (October 1 through September 30 of following year). Monitoring sites for the colocated sampler program consist of a precipitation-sample collector and a continuously recording rain gage. The purposes of the colocated sampler program are to (1) evaluate potential bias in chemical concentrations resulting from upgrade of Aerochem Metrics Model 301 (ACM) collectors with new N-CON Systems, Inc., bucket-type (N-CON) collectors and (2) assess the variability in electronically recording precipitation gages. Sites are identified by NADP with a 4-character code where the 2 alpha characters indicate the State in which the site is located. For example, site AZ03 is site number 03 in Arizona. Location information for the sites is available on the NADP Web site at http://nadp.sws.uiuc.edu/.

\section{Statistical Methods}

In this report, nonparametric, rank-based statistical methods are used in place of traditional statistics and hypothesis testing. The sign test (Kanji, 2006) was used to evaluate whether the median of differences between two groups is significantly different from zero. Statistical tests were evaluated at the 95-percent significance level (alpha $[\alpha]=0.05$ ) unless otherwise noted. Statistical analysis was performed using SAS version 9.2 software (SAS Institute Inc., 2001) and R version 3.2.3 (R Core Team, 2013).

Bias was quantified using relative and absolute differences and percent differences (Wetherbee and others, 2010). These parameters are calculated for each program, as follows.

$$
\begin{gathered}
\text { Relative difference }=\mathrm{Cn}-\mathrm{Cc}, \\
\text { Absolute difference }=|\mathrm{Cn}-\mathrm{Cc}|, \\
\text { Relative percentage difference }(\mathrm{RPD})= \\
{[(\mathrm{Cn}-\mathrm{Cc}) / \mathrm{Ct}] \bullet 100,} \\
\text { and } \\
\text { Absolute percentage difference }(\mathrm{APD})= \\
|(\mathrm{Cn}-\mathrm{Cc}) / \mathrm{Ct}| \cdot 100,
\end{gathered}
$$

where

$\mathrm{Cn}$ is the sample concentration, in milligrams per liter or nanograms per liter, for the test sample, or precipitation depth in centimeters;

$\mathrm{Cc}$ is the sample concentration, in milligrams per liter or nanograms per liter, for the control sample or precipitation depth in centimeters; and

$\mathrm{Ct}$ is either Cc (field audit and system blank programs), a most probable target value (interlaboratory comparison programs), or the mean of $\mathrm{Cn}$ and $\mathrm{Cc}$ for replicate measurements using identical rain gages (colocated sampler program).

Variability was quantified in this report using $f$-pseudosigma ( $f$-psig), a nonparametric analog of the standard deviation of a statistical sample (Hoaglin and others, 1983):

$$
f \text {-pseudosigma }=\frac{75 \text { th percentile }-25 \text { percentile }}{1.349}
$$

The $f$-pseudosigma ratio ( $f$-psig ratio) was also used to compare an entire dataset's variability with a subset's variability:

$$
f \text {-psig ratio }=\left(\frac{f p s i g_{\text {subset }}}{f p s i g_{o}}\right)
$$

where

$$
\begin{aligned}
& f_{p s i g} \text { is the } f \text {-pseudosigma of the subset, and } \\
& f p s i g \text { is the overall } f \text {-pseudosigma of the } \\
& \text { entire dataset. }
\end{aligned}
$$

An $f$-psig ratio less than 1 indicates less variability in the subset than the entire dataset, and an $f$-psig ratio greater than 1 indicates more variability in the subset than the entire dataset.

Data variability was evaluated to quantify precipitationsample stability and contamination levels. Maximum contamination levels were determined by a calculation of upper confidence limits (UCL) on percentiles of concentration data using a binomial distribution (Hahn and Meeker, 1991). Before determining contamination levels, concentrations less than the method detection limit (MDL) were changed to one-half the MDL. Helsel (2012) shows how such substitution leads to bias in hypothesis tests and calculation of statistical locations, but for this report, the substitution of half the detection limit had a minor effect as the percentage of censored values was typically less than 25 percent and was seen to have no discernable effect on quantification of the medians and interquartile ranges. Therefore, one-half the MDL was a convenient substitution for purposes of capturing reasonable estimates of bias and variability using the nonparametric methods described earlier (Gibbons and Coleman, 2001).

Hahn and Meeker (1991) describe a method for determining a distribution-free UCL for a percentile, which is appropriate for skewed data. This method uses order statistics, which are based on ranking the data from lowest to highest and applying binomial probability to determine the UCL. The binomial function $(B)$ is used to calculate the probability 
that no more than $(n-u)$ values from a total of $n$ observations exceed the $100(p)$ th percentile of the sampled population. The rank $(u)$ is chosen as the smallest integer such that

$$
B(u-1, n, p)>1-\alpha .
$$

The value of the 100(1- $\alpha)$ percent UCL for the 100th percentile of contamination in the population, then, is determined by the measured value of the $u$-ranked observation. For example, in a group of 100 field audit paired differences, the 95-percent UCL for the 90th percentile can be determined using equation 8 by finding the smallest value of $u$ that meets the criterion of 0.95 :

$$
B(u-1,100,0.90)>0.95 .
$$

For $u=95, B=0.942$, which is less than the criterion of 0.95 ; but for $u=96, B=0.976$, which meets the criterion. Thus the value of the 95-percent UCL is determined by the concentration of the 96th ranked paired difference (Mueller and Titus, 2005). This technique is used herein to estimate contamination limits in NADP samples.

Overall variability of NADP measurements was evaluated using colocated precipitation collectors and gages, which generated pairs of replicate measurements of the same parameters at the same time and place using similar field instruments. Measurement of the variability of NADP results was useful in the verification of trends in NADP data. Dissimilar colocated precipitation collectors and (or) gages, however, produced paired measurements that were used to evaluate instrumentation bias, which was evaluated for the identification of potential shifts in trends that resulted from the network retrofit with new instrumentation. Methods used to evaluate overall variability of data and instrumentation bias are discussed in more detail in Wetherbee and others (2005a, 2006, 2009, 2010).

\section{National Trends Network Quality Assurance Programs}

The PCQA operates the (1) field audit program, (2) interlaboratory comparison program, and (3) collocated sampler program to help enhance the quality of NTN data. The field audit program evaluates sample contamination and stability to ensure that NTN samples are representative of natural precipitation. The interlaboratory comparison program tests the performance of the CAL. The colocated sampler program evaluates the overall variability of NTN data when identical instruments are colocated, and instrument bias is evaluated when dissimilar instruments are colocated.

\section{Field Audit Program}

The field audit program uses equipment-rinse samples (bucket sample) paired with corresponding deionized water or synthetic precipitation solutions (bottle sample) to identify changes to chemical concentrations in NTN wet-deposition samples resulting from field exposure of the sample-collection apparatus (Latysh and Wetherbee, 2005; Wetherbee and others, 2010). After a week without wet deposition, site operators pour 75 percent of the volume of their field audit solution into the sample bucket, and the bucket is sealed with a lid for 24 hours prior to decanting to a clean sample bottle (bucket sample). The 25 percent of the field audit sample volume that remains in the sample bottle (bottle sample) never contacts any field sampling materials.

Contamination can be introduced to NADP samples by dissolution of materials residing on the bucket walls. Conversely, loss of dissolved constituents from the solution is possible through adsorption to the bucket walls and other chemical or biological processes. Contamination and sample stability are evaluated for network data by statistical analysis of paired "bucket-minus-bottle" concentration differences for field audit samples.

An NADP site operator who either processed and submitted a field audit sample to the Central Analytical Laboratory (CAL; Illinois State Water Survey) or notified the USGS that an attempt was made to process the field audit sample during the year was considered to have participated in the field audit program. Different sites were selected for participation each year. Of the 100 sites receiving samples each year, 56 percent of the sites participated during 2013, and 45 percent participated during 2014. Of the 56 sites participating in 2013, 55 pairs of samples were submitted samples for analysis. Of the 45 sites participating in 2014, 44 pairs of samples were submitted for analysis.

\section{Network Maximum Contamination Levels}

Maximum concentrations of contaminants in NTN samples, with statistical confidence, were estimated by the 90-, 95-, and 99-percent UCLs for selected percentiles of the field audit, bucket-minus-bottle paired differences using the binomial probability distribution function in SAS (SAS Institute, Inc., 2001) to apply equation 8 . The 90-percent UCLs for the 90th percentiles of field audit paired concentration differences are calculated for each analyte, and these values are considered the annual network maximum contamination levels (NMCLs). The NMCLs serve as practical lower limits of quantitation for network-measured wet-deposition of chemical constituents (Wetherbee and others, 2010, 2013a).

The NMCL can be defined in three ways: (1) the NMCL is the maximum contamination expected in 90 percent of the samples with 90-percent confidence, (2) there is a 10-percent chance that contamination in NTN samples has been underestimated at the NMCL, or (3) there is 90-percent confidence that the contamination would exceed the NMCLs in 10 percent of the NTN samples. The 95- and 99-percent UCLs are also shown herein for future reference in case NADP data quality objectives for NMCLs change. 
The 25th and 75th percentile values for all 2012-14 NTN monitoring data (Christopher M.B. Lehmann, Central Analytical Laboratory, University of Illinois, written commun, 2015) are compared to estimated annual NMCLs in table 1. The NMCL for potassium was $0.011 \mathrm{mg} / \mathrm{L}$, which was equal to the 25 th percentile of all 2012-14 NTN data. Therefore, the lower 25 percent of all potassium concentrations could result from contamination. The NMCL for calcium was $0.046 \mathrm{mg} / \mathrm{L}$, which equated to the $22 \mathrm{~d}$ percentile of all 2012-14 NTN data. Thus, the lower 22 percent of 2012-14 calcium concentrations could also result from contamination. Maximum values for analyte losses were less than or equal to the 2013 or 2014 method detection limits (MDLs), which indicated that analyte losses from NTN samples were negligible.

The 2013-14 results were combined with 2012 results to update the calculation of 3-year moving NMCLs. The 3-year moving NMCLs for calcium, nitrate, and sulfate continued to increase during 2012-14 (fig. 1). Sodium and chloride NMCLs decreased during 2012-14, while NMCLs for magnesium, potassium, ammonium, and hydrogen ion remained relatively constant.

\section{Analyte Losses}

The 2013-14 results were combined with 2012 results to update the calculation of 3-year moving analyte losses. Ammonium and nitrate losses continued to be lower than previous years (fig. 2), possibly because of treatment of the reused sample buckets with 3-percent (volume:volume) hydrogen peroxide used for disinfection prior to washing with de-ionized water (Nina Gartman, University of Illinois, written commun., December 2013). Hydrogen-ion contamination has trended downward since 2008 (fig. 1), whereas hydrogen-ion loss has been consistently between 3.0 and 3.7 microequivalents per liter ( $\mu$ eq/L) for the past 4 years (fig. 2).

\section{National Trends Network Interlaboratory Comparison Program}

The standing objectives of the NTN interlaboratory comparison program are (1) to estimate the variability and bias in data reported by CAL and other participating laboratories and (2) to facilitate integration of data from various wet-deposition monitoring networks, without any attempt to account for the different onsite protocols used by different monitoring networks. Eight laboratories participated in the interlaboratory comparison program during the 2013-14 study period: (1) Asia Center for Air Pollution Research (ACAP) in Niigata-shi, Japan; (2) CAL, Illinois State Water Survey, in Champaign, Illinois; (3) AMEC Foster Wheeler (2014), formerly AMEC, Inc., (2013), in Gainesville, Florida; (4) Ministry of Environment and Climate ChangeDorset Chemistry Laboratory (MOECC), in Dorset, Ontario, Canada; (5) Environment and Climate Change Canada (formerly Environment Canada in 2013-14) Science and Technology Branch (ECST) in Downsview, Ontario, Canada; (6) Norwegian Institute for Air Research (NILU) in Kjeller, Norway; (7) Carey Institute of Ecosystem Studies (CIES), in Millbrook, New York; and (8) U.S. Department of Agriculture Forest Service, Northern Research Station (NRS), in Durham, New Hampshire.

Each of the eight participating laboratories received four samples from BQS every month for chemical analysis. The three types of samples used in the interlaboratory comparison program included (1) synthetic standard reference samples prepared by BQS, which are traceable to National Institute of Standards and Technology (NIST) reference materials (NIST-traceable samples); (2) de-ionized water blanks samples prepared by BQS; and (3) natural wet-deposition

Table 1. National Atmospheric Deposition Program's National Trends Network method detection limits, network maximum contamination levels, and analyte losses calculated from field audit samples in addition to calculated concentration quartiles for all valid monitoring data, 2012-14.

[NTN, National Trends Network; MDL, method detection limit; NMCL, network maximum contamination level; NADP NTN, National Atmospheric Deposition Program National Trends Network; Q1, 25th percentile; Q3, 75th percentile; all units in milligram per liter except hydrogen ion (microequivalents per liter); n.d., no data]

\begin{tabular}{|c|c|c|c|c|c|c|c|}
\hline \multirow[t]{2}{*}{ Analyte } & \multicolumn{2}{|c|}{$\begin{array}{c}\text { NTN Method } \\
\text { detection limits } \\
\text { (MDL) }\end{array}$} & \multirow{2}{*}{$\begin{array}{c}\text { Network maximum } \\
\text { contamination level } \\
\text { (NMCL) }^{1} \\
2012-14 \\
\end{array}$} & \multirow{2}{*}{$\begin{array}{c}\begin{array}{c}\text { Maximum } \\
\text { analyte loss }\end{array} \\
2012-14 \\
\end{array}$} & \multicolumn{3}{|c|}{$\begin{array}{c}\text { Valid 2012-14 } \\
\text { NADP NTN data } \\
\text { quartile values }^{3}\end{array}$} \\
\hline & 2013 & 2014 & & & 01 & Median & 03 \\
\hline Magnesium & 0.009 & 0.005 & 0.010 & 0.001 & 0.012 & 0.024 & 0.049 \\
\hline Sodium & 0.002 & 0.005 & 0.012 & 0.003 & 0.021 & 0.052 & 0.148 \\
\hline Potassium & 0.001 & 0.001 & 0.011 & 0.001 & 0.011 & 0.021 & 0.041 \\
\hline Nitrate & 0.025 & 0.007 & 0.075 & 0.004 & 0.411 & 0.738 & 1.208 \\
\hline Sulfate & 0.005 & 0.005 & 0.047 & 0.014 & 0.328 & 0.609 & 1.018 \\
\hline Hydrogen ion & n.d. & n.d. & 0.930 & 3.490 & 1.445 & 5.129 & 10.233 \\
\hline
\end{tabular}

${ }^{1,2}$ Calculated as the 90 -percent upper confidence limits for the 90th percentiles of $2012 \neg 14$ field audit paired differences using the binomial distribution function in SAS (SAS Institute, Inc., 2001), where differences are calculated as (1) bucket-minus-bottle and (2) bottle-minus-bucket.

${ }^{3}$ Data for all valid 2012-14 NTN samples obtained from Christopher M.B. Lehmann, University of Illinois Prairie Research Institute, Illinois State Water Survey, written commun., 2015. 

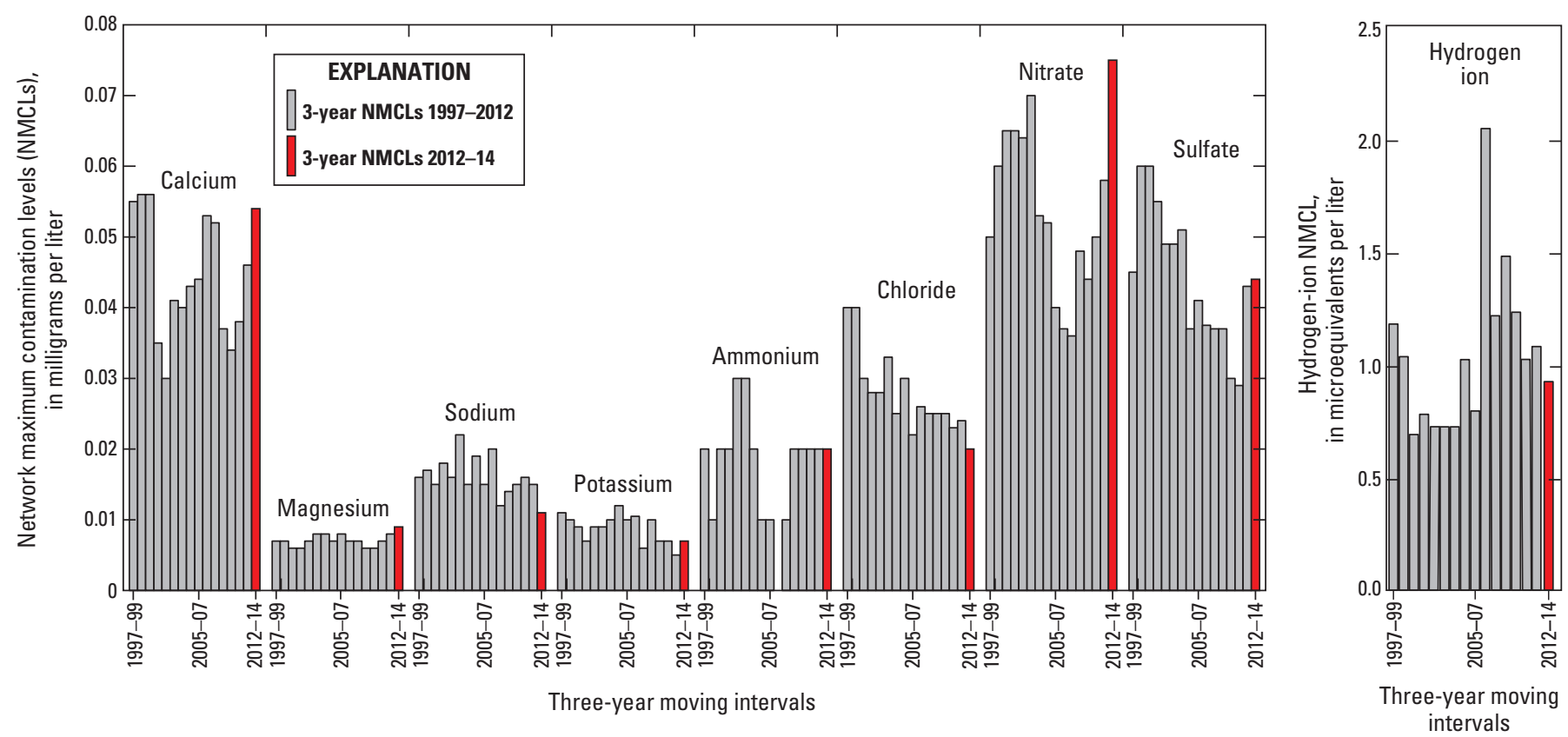

Figure 1. Network maximum contamination levels for National Trends Network analytes calculated by 3-year moving intervals, 1997-2014.

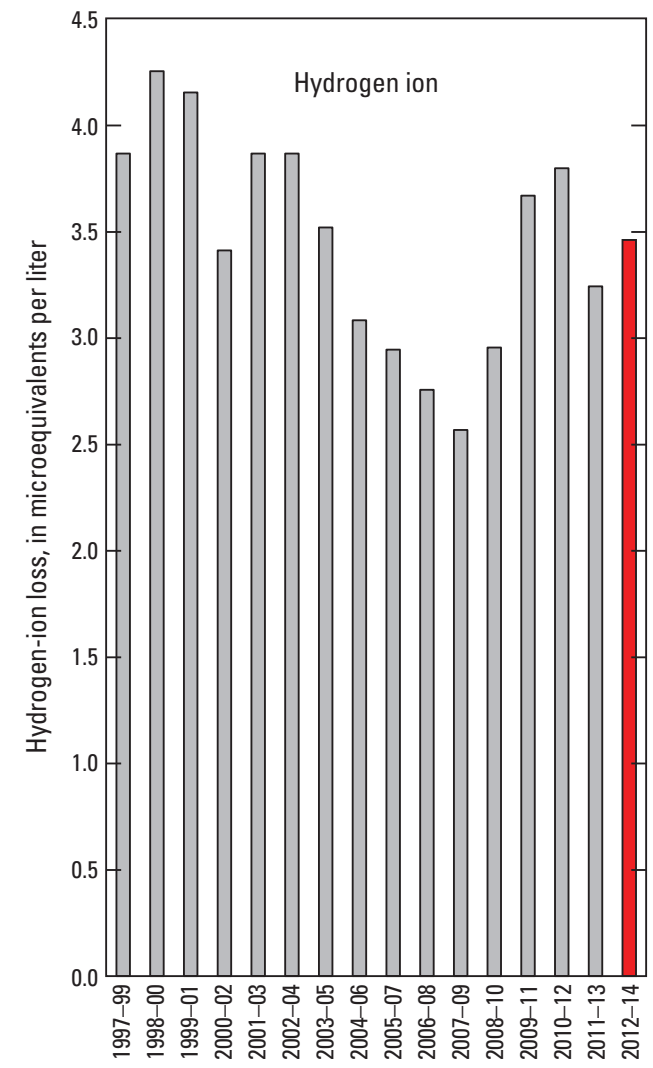

Three-year moving intervals

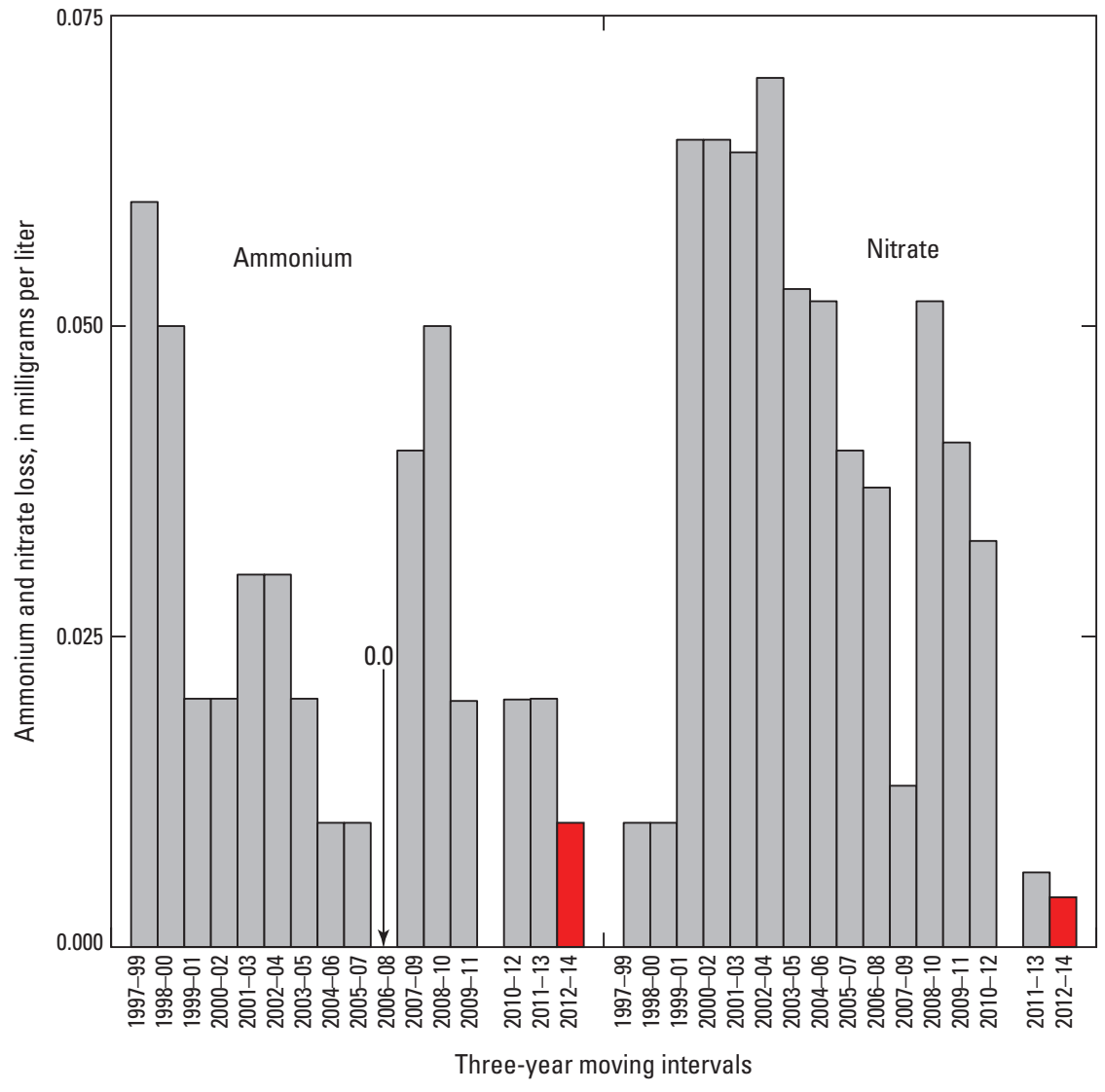

Figure 2. Maximum loss of hydrogen ion, ammonium, and nitrate from weekly National Trends Network samples calculated by 3-year moving intervals, 1997-2014. 
samples collected at NTN sites, blended by CAL, and sent to $\mathrm{BQS}$ for shipping to the laboratories as blind samples (Latysh and Wetherbee, 2005). Synthetic precipitation samples used in the interlaboratory comparison program were made from stock solutions prepared by High Purity Standards, Charleston, South Carolina. Natural samples were filtered through 0.45-micrometer $(\mu \mathrm{m})$ filters; bottled in 60-, 125-, and 250-milliliter $(\mathrm{mL})$ polyethylene bottles by CAL; and shipped in chilled, insulated containers to the BQS to enhance stability of nutrient analytes - ammonium, nitrate, and sulfate - in the samples (Tchobanoglous and Schroeder, 1987; Wilde and others, 2004).

Median concentrations for calcium, magnesium, sodium, potassium, ammonium, chloride, nitrate, sulfate, bromide, and hydrogen-ion and median specific conductance were computed by solution from the data submitted by the eight laboratories. The median values were considered to be equal to the most probable values (MPVs). Censored concentration values reported as less than the MDL are included in the estimation of MPVs for each solution using the Kaplan Meier method (Helsel, 2012). The largest percentages of censored concentration values observed for this program in 2013-14 were for magnesium and potassium, most commonly with natural wetdeposition samples.

The MPVs for the synthetic solutions and the number of samples analyzed per solution are listed in table 2. Data from each laboratory were compared against these MPVs to evaluate bias. Only CAL, NRS, and CIES analyzed the samples for bromide. The ECST laboratory does not analyze the samples for specific conductance.

\section{Interlaboratory Comparison Program Bias and Variability}

Interlaboratory bias for the participating laboratories was evaluated by the following methods: (1) comparison of the medians of the differences between laboratory results and MPVs, (2) hypothesis testing using the sign test, and (3) comparison of laboratory results for de-ionized water samples. The arithmetic signs of the median differences indicate whether the reported results for each constituent are positively or negatively biased. The sign test null hypothesis is "The true median of the reported-minus-MPV differences is zero." Test results were evaluated at the $\alpha=0.05$ significance level for a two-tailed test.

Calculated variation between laboratories was compared using the $f$-psig ratios (eq. 4). Tables 3 and 4 contain results from evaluating variability and bias within the analytical data reported by each of the participating laboratories. Shaded values in tables 3 and 4 identify analytes for which both (1) a statistically significant bias $(\alpha=0.05)$ was indicated by the sign test and (2) the absolute value of the median relative concentration difference was greater than the participant's analytical method detection limit (bottom of table 5).
During 2013, no significant absolute bias was observed for AMEC and NILU results, but significant absolute bias above the magnitudes of the detection limits was observed for ACAP (chloride, nitrate, and sulfate), CAL (chloride), MOECC (calcium and chloride), ECST (ammonium and sulfate), NRS (ammonium), and CIES (calcium) (table 3). During 2014, no significant bias was identified for any analytes for CAL, AMEC, NILU, and CIES, but significant bias above the method detection limits was identified for ACAP (magnesium, nitrate and sulfate), MOECC (chloride, bromide, and sulfate), ECST (calcium, nitrate, and sulfate), and NRS (hydrogen ion) (table 4).

The CAL, AMEC, ECST, and CIES laboratories had comparable, low overall variability among the participating laboratories during 2013-14 as indicated by their $f$-psig ratios (tables 3 and 4). The ACAP laboratory exhibited high variability for sodium during 2014. During 2013, the MOECC laboratory exhibited high variability for magnesium, potassium, and sulfate concentration results, and for ammonium, chloride, and sulfate results during 2014. The NILU laboratory reported potassium results with high variability in both 2013 and 2014. Analyses submitted by NRS indicated highly variable ammonium and specific conductance results during 2013 and both highly biased and variable hydrogen ion results during 2013-14.

Four de-ionized water blanks were analyzed annually by each laboratory. The ACAP laboratory reported detections in blanks for calcium (4), sodium (2), potassium (2), ammonium (4), chloride (1), nitrate (1), and sulfate (1) during 2013-14 (table 5). The CAL's results for de-ionized water blanks included 1 detection for calcium and 1 detection for sulfate greater than the MDLs during 2014. The AMEC Laboratory reported 1 detection each for ammonium and nitrate in deionized water blanks during 2014. The MOECC Laboratory reported 1 detection for ammonium in a blank during 2013, and ECST reported 1 detection for calcium in a blank during 2014. The NILU Laboratory reported no detected analytes in blanks during 2013, but during 2014, their blank sample results included detections for calcium (1), sodium (3), potassium (3), ammonium (2), chloride (3), and sulfate (1). During 2013, NRS reported detections of ammonium, chloride, and sulfate in 3 blank samples, and detections for ammonium (3) and sulfate (1) were reported for blanks during 2014. The CIES Laboratory reported 1 sulfate detection in a blank sample during 2014.

\section{Interlaboratory Comparison Program Control Charts}

Each participating laboratory's results were compared to the MPVs over time as shown in the control charts, which are viewable on the PCQA Web site at https://bqs.usgs.gov/PCQA/ Interlaboratory_Comparison/graphOutput.php?page=start. The 
Table 2. Analyte most probable values for synthetic precipitation solutions used in the 2013-14 National Trends Network interlaboratory comparison program.

$\left[\mathrm{Ca}^{2+}\right.$, calcium; $\mathrm{Mg}^{2+}$, magnesium; $\mathrm{Na}^{+}$, sodium; $\mathrm{K}^{+}$, potassium; $\mathrm{NH}_{4}^{+}$, ammonium; $\mathrm{Cl}^{-}$, chloride; $\mathrm{Br}^{-}$, bromide; $\mathrm{NO}_{3}^{-}$, nitrate; $\mathrm{SO}_{4}^{2-}$, sulfate; $\mathrm{H}^{+}$, hydrogen ion; all units in milligrams per liter except hydrogen ion (microequivalents per liter) and specific conductance (microsiemens per centimeter at 25 degrees Celsius); n.d., no data; ]

\begin{tabular}{|c|c|c|c|c|c|c|c|c|c|c|c|c|}
\hline \multirow[b]{2}{*}{ Solution } & \multicolumn{12}{|c|}{ Analytes } \\
\hline & $\mathrm{Ca}^{2+}$ & $\mathbf{M g}^{2+}$ & $\mathrm{Na}^{+}$ & $\mathbf{K}^{+}$ & $\mathrm{NH}_{4}^{+}$ & $\mathrm{Cl}^{-}$ & $\mathrm{Br}^{-}$ & $\mathrm{NO}_{3}^{-}$ & $\mathrm{SO}_{4}^{2-}$ & $\mathbf{H}^{+}$ & $\begin{array}{c}\text { Specific } \\
\text { conductance }\end{array}$ & $\begin{array}{c}\text { Number } \\
\text { of samples } \\
\text { analyzed }\end{array}$ \\
\hline SP1B & 0.441 & 0.090 & 0.407 & 0.077 & 0.677 & 0.572 & 0.076 & 2.031 & 3.720 & 39.8 & 29.4 & 31 \\
\hline SP10B & 0.219 & 0.045 & 0.202 & 0.037 & 0.340 & 0.296 & 0.038 & 1.027 & 1.925 & 19.7 & 15.3 & 8 \\
\hline SP17B & 0.057 & 0.012 & 0.053 & 0.010 & 0.105 & 0.075 & 0.009 & 0.265 & 0.484 & 6.38 & 4.6 & 22 \\
\hline SP3 & 0.153 & 0.048 & 0.105 & 0.024 & 0.150 & 0.161 & n.d. & 1.040 & 0.930 & 15.0 & 10.2 & 30 \\
\hline \multicolumn{13}{|c|}{2014} \\
\hline SP1B & 0.440 & 0.090 & 0.405 & 0.074 & 0.669 & 0.577 & 0.079 & 2.026 & 3.715 & 40.7 & 28.5 & 30 \\
\hline SP17B & 0.055 & 0.011 & 0.054 & 0.010 & 0.090 & 0.074 & 0.011 & 0.262 & 0.496 & 6.46 & 4.4 & 30 \\
\hline SP2B & 0.442 & 0.069 & 0.351 & 0.059 & 0.550 & 0.440 & 0.041 & 2.890 & 2.250 & 30.2 & 23.2 & 35 \\
\hline SP21B & 0.225 & 0.034 & 0.179 & 0.030 & 0.280 & 0.224 & 0.021 & 1.476 & 1.154 & 15.5 & 11.8 & 24 \\
\hline
\end{tabular}

CAL's control charts for 2013-14 are shown in figures $3 A$ and $3 B$. Points in the control charts in figures $3 A$ and $3 B$ are colorand symbol-coded by solution type to provide a visual indication of potential bias for specific solutions. One concentrationdifference value for magnesium and two for chloride exceeded the control limits ( $\pm 3 f$-psig) for CAL. Three nitrate concentration differences exceeded the control limits for CAL as well (fig. 3A). The control charts for magnesium, nitrate, and sulfate, wherein most points plot below the zero-difference line, indicate that CAL's analyses for these ions had a small negative bias during most of 2013-14 (figs. $3 A$ and $3 B$ ).

The control charts for bromide and specific conductance also exhibited a small negative bias for bromide and small positive bias for specific conductance (fig. $3 B$ ). The hydrogenion control chart shows 3 values outside the negative control limit specifically for the SP1B solution (fig. $3 B$ ). Subsequent hydrogen-ion determinations later in 2014 for SP1B were also negatively biased.

\section{Colocated Sampler Program}

The colocated sampler program evaluated (1) potential bias in NTN chemical constituent concentrations introduced by use of new N-CON precipitation collectors as replacements for aging ACM precipitation collectors (Wetherbee and others, $2009,2010)$ and (2) the variability of electronically recording precipitation gages. Colocated ACM and N-CON collectors were operated at Alamosa, Colo., (CO00) and at Niwot Ridge, Colo., (CO02) during water year 2013. For water year 2014, the colocated collectors were operated at Lake Scott State Park, Kansas, (KS32) and Great Smoky Mountains National
Park, Tenn. (TN11). Identical Environmental Technologies, Inc., (ETI) Noah IV or OTT Pluvio-2 precipitation gages were colocated to evaluate variability in these electronically recording gages. The $\mathrm{CO} 02$ site had a Belfort model 5-780 rain gage. Therefore, no electronically recording precipitation gages were colocated at $\mathrm{CO} 02$. Instead, a pair of ETI Noah IV precipitation gages were colocated at the Fort Collins MDN site (CO13), which was operated by Colorado State University. Paired OTT Pluvio-2 gages were colocated at CO00. During water year 2014, ETI Noah IV precipitation gages were colocated at TN11, and OTT Pluvio-2 precipitation gages were colocated at KS32.

An additional pair of colocated sites (CO98 and CO89) was operated by the USGS Fort Collins Science Center at Loch Vale, Rocky Mountain National Park, Colo. The purpose of the colocated instruments at the Loch Vale site was to quantify variability of total nitrogen wet-deposition monitoring for the National Park Service; the data are also useful for NADP quality assurance purposes (Morris and others, 2014). Sites CO98 and CO89 each had colocated ETI Noah IV precipitaton gages and ACM collectors during the study period. Table 6 lists specifications for the colocated site identifiers and field instrumentation.

At each colocated site, precipitation collectors and gages were installed between 5 and 30 meters apart with exposure to identical environmental conditions as much as possible. Raingage shielding and other accessories were duplicated. Proper operation of each set of colocated equipment, per manufacturer specifications and NADP criteria, was verified by the USGS before using the data from the colocated sites (Dossett and Bowersox, 1999). Colocated sites were operated using identical field and laboratory sample collection and analysis procedures. 
Table 3. Median differences between reported concentrations and most probable values for synthetic wet-deposition samples, 2013 interlaboratory comparison program.

[ACAP, Asia Center for Air Pollution Research; CAL, Central Analytical Laboratory, Illinois State Water Survey; AMEC, AMEC, Inc.; MOECC, Ministry of Environment and Climate Change--Dorset Chemistry Laboratory; ECST, Environment and Climate Change Canada (formerly [2013-14] Environment Canada) Science and Technology Branch; NILU, Norwegian Institute for Air Research; NRS, U.S. Department of Agriculture Forest Service, Northern Research Station; CIES, Carey Institute of Ecosystem Studies; all units in milligrams per liter (mg/L) except hydrogen ion (microequivalents per liter) and specific conductance (microsiemens per centimeter at 25 degrees Celsius); overall $f$-psig, $f$-pseudosigma for all participating laboratories; median diff., median of differences between each laboratory's individual results and the most probable value during 2013; $f$-psig ratio, ratio of each individual laboratory's $f$-pseudosigma to the overall $f$-pseudosigma, in percent; $\%$, percent; sign test $p$-value, probability of rejecting the null hypothesis: "The true median of the differences between laboratory results and the most probable value is zero," when true; values are shaded where median bias is greater than the method detection limit (table 5) and statistically significant ( $\alpha=0.05$ ) (Kanji, 2006); Spec. cond., specific conductance; --, not calculated; <, less than]

\begin{tabular}{|c|c|c|c|c|c|c|c|c|c|c|c|c|c|}
\hline \multirow[b]{3}{*}{ Analyte } & \multirow[b]{3}{*}{$\begin{array}{l}\text { Overall } \\
f \text {-psig }\end{array}$} & \multicolumn{12}{|c|}{ Laboratory } \\
\hline & & \multicolumn{3}{|c|}{ ACAP } & \multicolumn{3}{|c|}{ CAL } & \multicolumn{3}{|c|}{ AMEC } & \multicolumn{3}{|c|}{ MOECC } \\
\hline & & $\begin{array}{l}\text { Median } \\
\text { diff. }\end{array}$ & $\begin{array}{c}\text { Sign } \\
\text { test } \\
p \text {-value }\end{array}$ & $\begin{array}{c}f \text {-psig } \\
\text { ratio } \\
(\%)\end{array}$ & $\begin{array}{c}\text { Median } \\
\text { diff. }\end{array}$ & $\begin{array}{c}\text { Sign } \\
\text { test } \\
p \text {-value }\end{array}$ & $\begin{array}{c}f \text {-psig } \\
\text { ratio } \\
(\%)\end{array}$ & $\begin{array}{l}\text { Median } \\
\text { diff. }\end{array}$ & $\begin{array}{c}\text { Sign } \\
\text { test } \\
p \text {-value }\end{array}$ & $\begin{array}{c}f \text {-psig } \\
\text { ratio } \\
(\%)\end{array}$ & $\begin{array}{c}\text { Median } \\
\text { diff. }\end{array}$ & $\begin{array}{c}\text { Sign } \\
\text { test } \\
p \text {-value }\end{array}$ & $\begin{array}{c}f \text {-psig } \\
\text { ratio } \\
(\%)\end{array}$ \\
\hline Calcium & 0.008 & 0.006 & 0.064 & 96 & 0.002 & 0.007 & 33 & -0.002 & $<0.001$ & 22 & 0.021 & 0.017 & 230 \\
\hline Magnesium & 0.002 & 0.001 & 0.308 & 300 & 0.000 & 0.774 & 40 & -0.001 & $<0.001$ & 40 & 0.000 & 1.000 & 460 \\
\hline Sodium & 0.006 & 0.004 & 0.001 & 47 & 0.001 & 0.099 & 88 & -0.002 & $<0.001$ & 88 & 0.000 & 0.210 & 181 \\
\hline Potassium & 0.003 & 0.000 & 0.774 & 22 & -0.001 & 0.001 & 22 & -0.001 & $<0.001$ & 44 & 0.001 & 0.359 & 478 \\
\hline Ammonium & 0.013 & 0.004 & 0.093 & 112 & -0.006 & 0.007 & 50 & -0.008 & 0.064 & 138 & -0.002 & 0.023 & 37 \\
\hline Chloride & 0.014 & 0.016 & $<0.001$ & 63 & 0.004 & 0.002 & 17 & -0.002 & 0.064 & 34 & -0.042 & 0.007 & 268 \\
\hline Bromide & 0.010 & -- & -- & -- & 0 & 0.289 & 9 & -- & -- & -- & -- & -- & -- \\
\hline Nitrate & 0.036 & 0.069 & $<0.001$ & 180 & 0.004 & 0.524 & 42 & -0.004 & 0.839 & 90 & -0.002 & 0.678 & 47 \\
\hline Sulfate & 0.039 & 0.028 & 0.002 & 171 & 0.014 & 0.308 & 58 & -0.013 & 0.405 & 80 & -0.102 & 0.064 & 799 \\
\hline Hydrogen ion & 2.447 & -2.324 & 0.003 & 51 & -0.928 & 0.152 & 52 & 1.993 & $<0.001$ & 179 & 5.423 & $<0.001$ & 165 \\
\hline Spec. cond. & 0.8 & -0.4 & $<0.001$ & 78 & 0.6 & $<0.001$ & 65 & 0.3 & $<0.001$ & 30 & 0.1 & 0.503 & 39 \\
\hline \multirow[b]{3}{*}{ Analyte } & \multirow[b]{3}{*}{$\begin{array}{l}\text { Overall } \\
f \text {-psig }\end{array}$} & \multicolumn{12}{|c|}{ Laboratory } \\
\hline & & \multicolumn{3}{|c|}{ ECST } & \multicolumn{3}{|c|}{ NILU } & \multicolumn{3}{|c|}{ NRS } & \multicolumn{3}{|c|}{ CIES } \\
\hline & & $\begin{array}{c}\text { Median } \\
\text { diff. }\end{array}$ & $\begin{array}{c}\text { Sign } \\
\text { test } \\
p \text {-value }\end{array}$ & $\begin{array}{c}f \text {-psig } \\
\text { ratio } \\
(\%)\end{array}$ & $\begin{array}{c}\text { Median } \\
\text { diff. }\end{array}$ & $\begin{array}{c}\text { Sign } \\
\text { test } \\
p \text {-value }\end{array}$ & $\begin{array}{c}f \text {-psig } \\
\text { ratio } \\
(\%)\end{array}$ & $\begin{array}{c}\text { Median } \\
\text { diff. }\end{array}$ & $\begin{array}{c}\text { Sign } \\
\text { test } \\
p \text {-value }\end{array}$ & $\begin{array}{c}f \text {-psig } \\
\text { ratio } \\
(\%)\end{array}$ & $\begin{array}{c}\text { Median } \\
\text { diff. }\end{array}$ & $\begin{array}{c}\text { Sign } \\
\text { test } \\
p \text {-value }\end{array}$ & $\begin{array}{c}f \text {-psig } \\
\text { ratio } \\
(\%)\end{array}$ \\
\hline Calcium & 0.008 & 0.005 & 0.007 & 39 & -0.015 & 0.210 & 300 & 0.000 & 1.000 & 57 & -0.013 & $<0.001$ & 126 \\
\hline Magnesium & 0.002 & 0.000 & 0.549 & 40 & 0.000 & 0.302 & 160 & -0.003 & 0.017 & 320 & 0.001 & 0.057 & 40 \\
\hline Sodium & 0.006 & 0.001 & 0.267 & 63 & 0.002 & 0.210 & 125 & -0.007 & 0.152 & 338 & 0.000 & 1.000 & 56 \\
\hline Potassium & 0.003 & 0.000 & 0.754 & 22 & -0.003 & 0.189 & 489 & -0.004 & 0.152 & 300 & 0.002 & 0.003 & 56 \\
\hline Ammonium & 0.013 & -0.006 & 0.007 & 35 & 0.002 & 0.023 & 94 & 0.936 & $<0.001$ & 6,399 & 0.006 & 0.001 & 71 \\
\hline Chloride & 0.014 & -0.001 & 1.000 & 45 & -0.004 & 0.832 & 153 & 0.014 & 0.839 & 157 & -0.001 & 0.824 & 33 \\
\hline Bromide & 0.010 & -- & -- & -- & -- & -- & -- & 0.008 & 0.007 & 243 & 0.002 & 0.210 & 113 \\
\hline Nitrate & 0.036 & 0.006 & 0.118 & 63 & 0.020 & 0.678 & 126 & -0.011 & 0.035 & 170 & -0.018 & 0.001 & 35 \\
\hline Sulfate & 0.039 & -0.022 & 0.007 & 78 & 0.021 & 0.308 & 68 & -0.002 & 0.308 & 294 & 0.009 & 0.096 & 50 \\
\hline Hydrogen ion & 2.447 & -0.687 & 0.007 & 41 & 0.171 & 0.308 & 40 & 3.115 & 0.308 & 291 & 0.703 & 0.263 & 55 \\
\hline Spec. cond. & 0.8 & -- & -- & -- & 0.5 & 0.0227 & 91 & -0.2 & 0.064 & 2,896 & -9.6 & $<0.001$ & 578 \\
\hline
\end{tabular}


Table 4. Median differences between reported concentrations and most probable values for synthetic wet-deposition samples, 2014 interlaboratory comparison program.

[ACAP, Asia Center for Air Pollution Research; CAL, Central Analytical Laboratory, Illinois State Water Survey; AMEC, AMEC Foster Wheeler (2014), formerly AMEC, Inc. (2013); MOECC, Ministry of Environment and Climate Change - Dorset Chemistry Laboratory; ECST, Environment and Climate Change Canada (formerly [2013-14] Environment Canada) Science and Technology Branch; NILU, Norwegian Institute for Air Research; NRS, U.S. Department of Agriculture Forest Service, Northern Research Station; CIES, Carey Institute of Ecosystem Studies; all units in milligrams per liter except hydrogen ion (microequivalents per liter) and specific conductance (microsiemens per centimeter at 25 degrees Celsius); overall $f$-psig, $f$-pseudosigma for all participating laboratories; median diff., median of differences between each laboratory's individual results and the most probable value during 2014; $f$-psig ratio, ratio of each individual laboratory's $f$-pseudosigma to the overall $f$-pseudosigma, in percent; $\%$, percent; sign test $p$-value, probability of rejecting the null hypothesis: "The true median of the differences between laboratory results and the most probable value is zero," when true; values are shaded where median bias is greater than the method detection limit (table 5 ) and statistically significant ( $\alpha=0.05$ ) (Kanji, 2006); Spec. cond., specific conductance; --, not calculated; <, less than]

\begin{tabular}{|c|c|c|c|c|c|c|c|c|c|c|c|c|c|}
\hline \multirow[b]{3}{*}{ Analyte } & \multirow[b]{3}{*}{$\begin{array}{l}\text { Overall } \\
f \text {-psig }\end{array}$} & \multicolumn{12}{|c|}{ Laboratory } \\
\hline & & \multicolumn{3}{|c|}{ ACAP } & \multicolumn{3}{|c|}{ CAL } & \multicolumn{3}{|c|}{ AMEC } & \multicolumn{3}{|c|}{ MOECC } \\
\hline & & $\begin{array}{c}\text { Median } \\
\text { diff. }\end{array}$ & $\begin{array}{c}\text { Sign } \\
\text { test } \\
p \text {-value }\end{array}$ & $\begin{array}{c}f \text {-psig } \\
\text { ratio } \\
(\%)\end{array}$ & $\begin{array}{c}\text { Median } \\
\text { diff. }\end{array}$ & $\begin{array}{c}\text { Sign } \\
\text { test } \\
p \text {-value }\end{array}$ & $\begin{array}{c}f \text {-psig } \\
\text { ratio } \\
(\%)\end{array}$ & $\begin{array}{c}\text { Median } \\
\text { diff. }\end{array}$ & $\begin{array}{c}\text { Sign } \\
\text { test } \\
p \text {-value }\end{array}$ & $\begin{array}{c}f \text {-psig } \\
\text { ratio } \\
(\%)\end{array}$ & $\begin{array}{c}\text { Median } \\
\text { diff. }\end{array}$ & $\begin{array}{c}\text { Sign } \\
\text { test } \\
p \text {-value }\end{array}$ & $\begin{array}{c}f \text {-psig } \\
\text { ratio } \\
(\%)\end{array}$ \\
\hline Calcium & 0.011 & 0.003 & 0.678 & 160 & 0.000 & 1.000 & 27 & -0.002 & 0.001 & 17 & -0.004 & 0.383 & 247 \\
\hline Magnesium & 0.004 & -0.005 & $<0.001$ & 280 & 0.000 & 0.006 & 40 & 0.000 & 0.375 & 10 & 0.000 & 0.481 & 80 \\
\hline Sodium & 0.006 & 0.005 & 0.093 & 1,000 & 0.002 & 0.078 & 69 & -0.003 & $<0.001$ & -1 & 0.004 & 0.017 & 50 \\
\hline Potassium & 0.003 & 0.002 & 0.286 & 563 & 0.000 & 1.000 & 13 & 0.000 & 0.754 & 50 & 0.003 & 0.017 & 175 \\
\hline Ammonium & 0.008 & 0.008 & 0.035 & 577 & 0.004 & 0.002 & 33 & -0.009 & 0.004 & 63 & -0.025 & $<0.001$ & 442 \\
\hline Chloride & 0.006 & 0.005 & 0.007 & 106 & 0.000 & 0.664 & 38 & 0.001 & 0.267 & 25 & -0.024 & $<0.001$ & 1,556 \\
\hline Bromide & 0.005 & -- & -- & -- & -0.001 & 0.004 & 77 & -- & -- & -- & -- & -- & -- \\
\hline Nitrate & 0.027 & 0.062 & $<0.001$ & 201 & -0.008 & 0.308 & 55 & -0.012 & 0.004 & 36 & 0.005 & 0.541 & 161 \\
\hline Sulfate & 0.045 & 0.029 & $<0.001$ & 136 & -0.011 & 0.152 & 34 & -0.016 & 0.001 & 21 & -0.054 & 0.011 & 1,291 \\
\hline Hydrogen ion & 3.147 & -2.899 & 0.002 & 263 & -0.101 & 1.000 & 35 & 1.491 & 0.021 & 34 & 4.373 & $<0.001$ & 173 \\
\hline \multirow[t]{3}{*}{ Spec. cond. } & 0.9 & -0.3 & 0.052 & 100 & 1.0 & $<0.001$ & 71 & 0.4 & 0.001 & 63 & 0.2 & 0.286 & 48 \\
\hline & & \multicolumn{12}{|c|}{ Laboratory } \\
\hline & & \multicolumn{3}{|c|}{ ECST } & \multicolumn{3}{|c|}{ NILU } & \multicolumn{3}{|c|}{ NRS } & \multicolumn{3}{|c|}{ CIES } \\
\hline Analyte & $\begin{array}{l}\text { Overall } \\
f \text {-psig }\end{array}$ & $\begin{array}{c}\text { Median } \\
\text { diff. }\end{array}$ & $\begin{array}{c}\text { Sign } \\
\text { test } \\
p \text {-value }\end{array}$ & $\begin{array}{c}f \text {-psig } \\
\text { ratio } \\
(\%)\end{array}$ & $\begin{array}{c}\text { Median } \\
\text { diff. }\end{array}$ & $\begin{array}{c}\text { Sign } \\
\text { test } \\
p \text {-value }\end{array}$ & $\begin{array}{c}f \text {-psig } \\
\text { ratio } \\
(\%)\end{array}$ & $\begin{array}{c}\text { Median } \\
\text { diff. }\end{array}$ & $\begin{array}{c}\text { Sign } \\
\text { test } \\
p \text {-value }\end{array}$ & $\begin{array}{c}f \text {-psig } \\
\text { ratio } \\
(\%)\end{array}$ & $\begin{array}{c}\text { Median } \\
\text { diff. }\end{array}$ & $\begin{array}{c}\text { Sign } \\
\text { test } \\
p \text {-value }\end{array}$ & $\begin{array}{c}f \text {-psig } \\
\text { ratio } \\
(\%)\end{array}$ \\
\hline Calcium & 0.011 & 0.008 & $<0.001$ & 37 & 0.002 & 0.678 & 97 & 0.002 & 1.000 & 190 & -0.009 & $<0.001$ & 127 \\
\hline Magnesium & 0.004 & 0.002 & $<0.001$ & 10 & 0.000 & 0.629 & 160 & -0.002 & 0.648 & 120 & 0.001 & $<0.001$ & 20 \\
\hline Sodium & 0.006 & 0.004 & 0.023 & 81 & 0.001 & 0.210 & 163 & -0.026 & $<0.001$ & 250 & 0.001 & 0.678 & 56 \\
\hline Potassium & 0.003 & 0.001 & 0.001 & 38 & 0.003 & 0.678 & 313 & -0.010 & 0.003 & 200 & 0.000 & 1.000 & 63 \\
\hline Ammonium & 0.008 & 0.002 & 0.210 & 91 & -0.002 & 0.210 & 65 & 0.007 & $<0.001$ & 65 & 0.001 & 0.664 & 47 \\
\hline Chloride & 0.006 & 0.001 & 0.359 & 50 & -0.006 & 0.093 & 159 & 0.023 & 0.003 & 216 & -0.001 & 0.524 & 56 \\
\hline Bromide & 0.005 & -- & -- & -- & -- & -- & -- & 0.009 & 0.004 & 123 & 0 & 0.238 & 42 \\
\hline Nitrate & 0.027 & 0.010 & 0.007 & 28 & 0.004 & 0.017 & 111 & -0.016 & $<0.001$ & 276 & -0.003 & 0.012 & 103 \\
\hline Sulfate & 0.045 & -0.027 & 0.023 & 65 & 0.034 & 0.064 & 109 & 0.056 & 0.824 & 238 & 0.006 & 0.001 & 33 \\
\hline Hydrogen ion & 3.147 & -0.697 & $<0.001$ & 22 & 0.180 & 0.839 & 48 & 46.024 & $<0.001$ & 116,778 & -0.353 & 0.308 & 18 \\
\hline Spec. cond. & 0.9 & -- & -- & -- & 0.1 & 0.286 & 96 & -1.0 & $<0.001$ & 142 & -3.5 & $<0.001$ & 475 \\
\hline
\end{tabular}


Table 5. Number of analyte determinations greater than the method detection limits by participating laboratory and by analyte for de-ionized water samples, 2013-14.

[ACAP, Asia Center for Air Pollution Research; CAL, Central Analytical Laboratory, Illinois State Water Survey; AMEC, AMEC, Inc.(2013), or AMEC-Foster Wheeler, Inc. (2014); MOECC, Ministry of Environment and Climate Change—Dorset Chemistry Laboratory; ECST, Environment and Climate Change Canada (formerly [2013-14] Environment Canada) Science and Technology Branch; NRS, U.S. Department of Agriculture, Forest Service Northern Research Service; CIES, Carey Institute of Ecosystem Studies; n.d., no data; mg/L, milligram per liter]

\begin{tabular}{|c|c|c|c|c|c|c|c|c|}
\hline Analyte & ACAP & CAL & AMEC & MOEEC & ECST & NILU & NRS & CIES \\
\hline \multicolumn{9}{|c|}{2013} \\
\hline Magnesium & 0 & 0 & 0 & 0 & 0 & 0 & 0 & 0 \\
\hline Potassium & 0 & 0 & 0 & 0 & 0 & 0 & 0 & 0 \\
\hline Ammonium & 2 & 0 & 0 & 1 & 0 & 0 & 3 & 0 \\
\hline Chloride & 0 & 0 & 0 & 0 & 0 & 0 & 3 & 0 \\
\hline Sulfate & 0 & 0 & 0 & 0 & 0 & 0 & 3 & 0 \\
\hline \multicolumn{9}{|c|}{2014} \\
\hline Calcium & 3 & 1 & 0 & 0 & 1 & 1 & 0 & 0 \\
\hline Magnesium & 0 & 0 & 0 & 0 & 0 & 0 & 0 & 0 \\
\hline Sodium & 1 & 0 & 0 & 0 & 0 & 3 & 0 & 0 \\
\hline Potassium & 2 & 0 & 0 & 0 & 0 & 3 & 0 & 0 \\
\hline Sulfate & 1 & 1 & 0 & 0 & 0 & 1 & 1 & 1 \\
\hline \multicolumn{9}{|c|}{ Method detection limits (mg/L) 2013-14 } \\
\hline \multicolumn{9}{|c|}{$2013-14$} \\
\hline Calcium & 0.004 & $0.027 / 0.019$ & 0.003 & 0.020 & 0.005 & 0.010 & 0.026 & 0.010 \\
\hline Magnesium & 0.001 & $0.009 / 0.005$ & 0.003 & 0.005 & 0.005 & 0.010 & 0.016 & 0.010 \\
\hline Sodium & 0.004 & $0.002 / 0.005$ & 0.005 & 0.005 & 0.005 & 0.010 & 0.051 & 0.010 \\
\hline Potassium & 0.002 & $0.001 / 0.001$ & 0.005 & 0.005 & 0.005 & 0.010 & 0.039 & 0.010 \\
\hline Ammonium & 0.011 & $0.016 / 0.017$ & 0.020 & 0.003 & 0.005 & 0.010 & 0.003 & 0.020 \\
\hline Chloride & 0.005 & $0.003 / 0.008$ & 0.020 & 0.010 & 0.005 & 0.010 & 0.030 & 0.020 \\
\hline Nitrate & 0.017 & $0.025 / 0.007$ & 0.035 & 0.009 & 0.005 & 0.010 & 0.025 & 0.020 \\
\hline Sulfate & 0.019 & $0.005 / 0.005$ & 0.040 & 0.050 & 0.005 & 0.010 & 0.030 & 0.020 \\
\hline
\end{tabular}

\section{ACM and N-CON Collector Comparison}

Weekly precipitation chemistry data from colocated sites were analyzed for differences between samples collected using ACM and N-CON collectors. Only data identified in the NADP by a laboratory-type code "W" as having sufficient volume for analysis without dilution were used (National Atmospheric Deposition Program, http://nadp.sws.uiuc.edu/ documentation/notes-wk.html, accessed February 3, 2015). Samples that required dilution or were flagged as contaminated by NADP were considered prone to a greater error component and were eliminated from statistical analysis. Only samples flagged by NADP with "A" or "B" quality rating codes were used, and samples with quality rating codes of type "C" were eliminated.

Because annual summaries of NTN data describe wetdeposition chemistry in terms of concentration and deposition (National Atmospheric Deposition Program, 2015), statistical summaries for both the concentration and deposition of constituents are provided. The weekly precipitation depth from the original site's recording precipitation gage was used to calculate deposition values at the colocated sites by multiplying precipitation-weighted mean concentrations for each analyte in milligrams per liter $(\mathrm{mg} / \mathrm{L})$ by 0.10 times the precipitation depth in centimeters $(\mathrm{cm})$ to yield deposition in kilograms per hectare $(\mathrm{kg} / \mathrm{ha})$ (Wetherbee and others, 2010).

\section{Weekly Concentration Values}

The N-CON-minus-ACM concentration differences were calculated from paired weekly samples to evaluate bias between collector types. Median weekly concentration differences were all positively signed except for hydrogen-ion concentration at 3 of the 4 colocated sampler study locations, which indicated that $\mathrm{N}-\mathrm{CON}$ concentrations generally were higher than ACM concentrations (tables 7 and 8). The N-CON generally catches larger sample volumes than the ACM because it is open more often than the ACM (Wetherbee and others, 2013a). This difference could be due to the N-CON collector opening earlier than the $\mathrm{ACM}$ at the onset of precipitation, thereby catching more washout at the beginning of precipitation events (Lynch and others, 1990). Paired weekly sample-volume differences indicated -1.4 to +23 median weekly relative percent differences in NTN sample-volume measurements for the 2013-14 study period. 


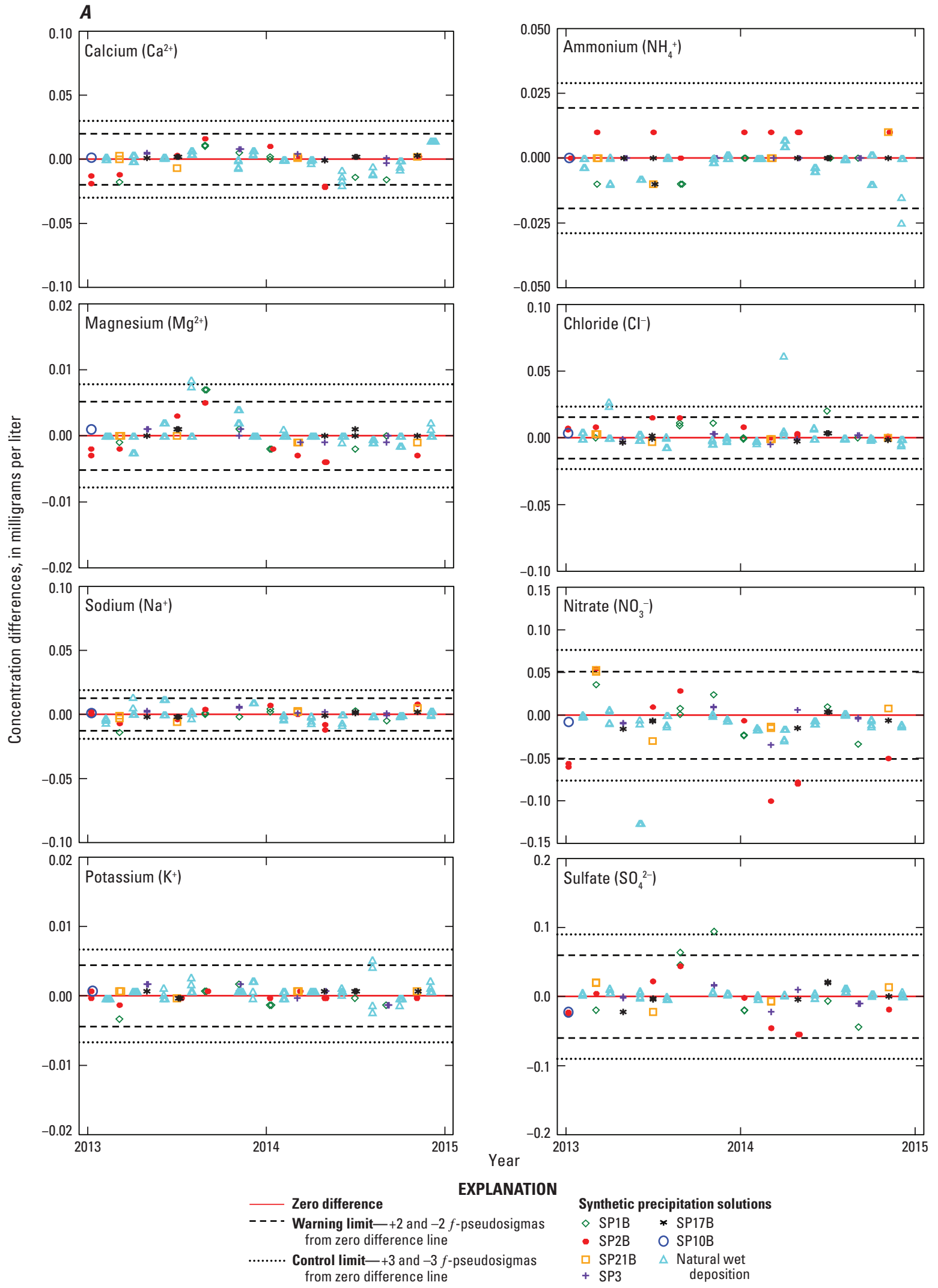

Figure 3. Differences between concentration values reported by the CAL and the median concentration values for all participating laboratories in the interlaboratory comparison program for the National Trends Network, 2013-14, calculated by solution for $(A)$ calcium, magnesium, sodium, potassium, ammonium, chloride, nitrate, and sulfate and $(B)$ bromide and hydrogen-ion concentrations and specific conductance. 

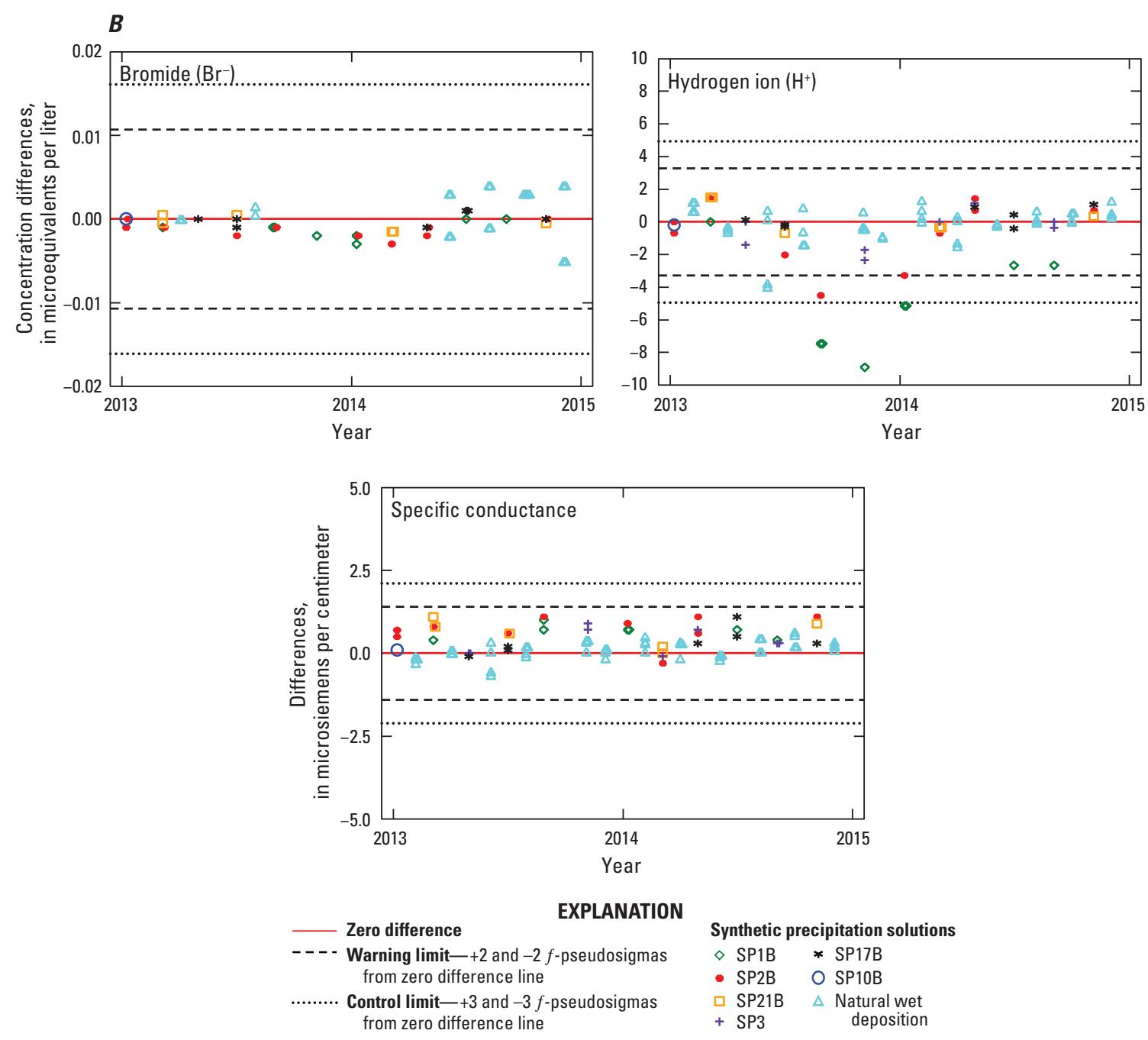

Figure 3. Differences between concentration values reported by the CAL and the median concentration values for all participating laboratories in the interlaboratory comparison program for the National Trends Network, 2013-14, calculated by solution for $(A)$ calcium, magnesium, sodium, potassium, ammonium, chloride, nitrate, and sulfate and $(B)$ bromide and hydrogen-ion concentrations and specific conductance.-Continued

Table 6. Field instrumentation, colocated National Trends Network sites, 2013-14.

[ID, site identifier; OTT, OTT division of HACH Company; ETI, Environmental Technologies, Inc.; ACM, Aerochem Metrics model 301 wet/dry precipitation collector; N-CON, N-CON Systems, Inc., bucket-type precipitation collector for National Trends Network; N-CON MDN, N-CON Systems, Inc., bottle-type precipitation collector for Mercury Deposition Network]

\begin{tabular}{|c|c|c|c|c|c|}
\hline \multicolumn{3}{|c|}{ Original site } & \multicolumn{3}{|c|}{ Colocated site } \\
\hline ID & $\begin{array}{l}\text { Precipitation gage } \\
\text { manufacturer/model }\end{array}$ & $\begin{array}{l}\text { Precipitation } \\
\text { collector }\end{array}$ & ID & $\begin{array}{c}\text { Precipitation gage } \\
\text { manufacturer/model }\end{array}$ & $\begin{array}{c}\text { Precipitation } \\
\text { collector }\end{array}$ \\
\hline \multicolumn{6}{|c|}{2013} \\
\hline $\mathrm{CO} 02$ & Belfort 5-780 & $\mathrm{ACM}$ & $02 \mathrm{CO}$ & none & $\mathrm{N}-\mathrm{CON}$ \\
\hline $\mathrm{CO} 13$ & ETI/Noah IV & $\mathrm{N}-\mathrm{CON} \mathrm{MDN}$ & $13 \mathrm{CO}$ & ETI/Noah IV & none \\
\hline \multicolumn{6}{|c|}{2014} \\
\hline \multicolumn{6}{|c|}{ 2013-14 } \\
\hline $\mathrm{CO} 98$ & ETI/Noah IV & $\mathrm{ACM}$ & CO89 & ETI/Noah IV & ACM \\
\hline
\end{tabular}


Table 7. Median weekly N-CON Systems Company, Inc.-minus-Aerochem Metrics parameter differences and annual deposition differences, water year 2013.

[CO00 and 00CO, Alamosa, Colorado; $\mathrm{CO} 02$ and 02CO, Niwot Ridge, Colorado; mg/L, milligram per liter; $\mu$ eq/L, microequivalent per liter; $\mu \mathrm{S} / \mathrm{cm}$, microsiemens per centimeter at 25 degrees Celsius; mL, milliliter; NA., not applicable]

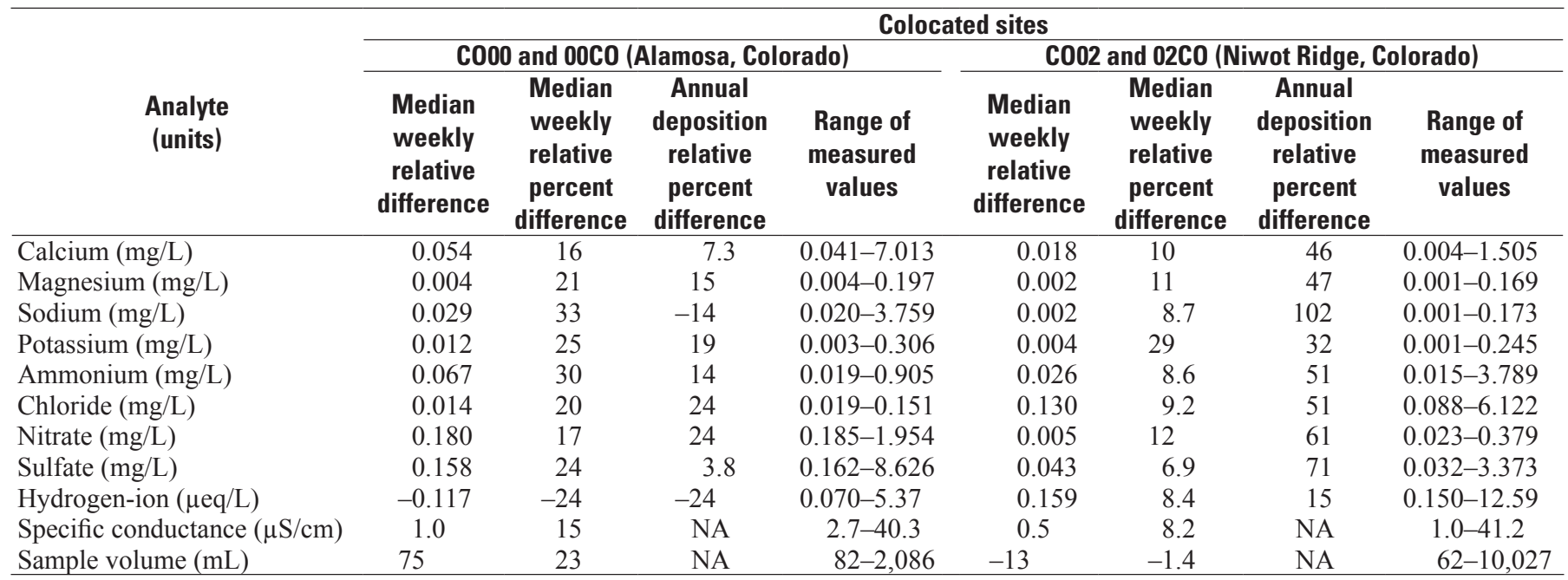

Table 8. Median weekly N-CON Systems Company, Inc.-minus-Aerochem Metrics parameter differences and annual deposition differences, water year 2014.

[KS32 and 32KS, Lake Scott State Park, Kansas; TN11 and 11TN, Great Smoky Mountains National Park, Tennessee; mg/L, milligrams per liter; $\mu$ eq/L, microequivalents per liter; $\mu \mathrm{S} / \mathrm{cm}$, microsiemens per centimeter; $\mathrm{mL}$, milliliters; NA., not applicable]

\begin{tabular}{|c|c|c|c|c|c|c|c|c|}
\hline \multirow[b]{3}{*}{$\begin{array}{l}\text { Analyte } \\
\text { (units) }\end{array}$} & \multicolumn{8}{|c|}{ Colocated sites } \\
\hline & \multicolumn{4}{|c|}{$\begin{array}{c}\text { Lake Scott State Park, Kansas } \\
\text { KS32 and 32KS }\end{array}$} & \multicolumn{4}{|c|}{$\begin{array}{c}\text { Great Smoky Mountains National Park, Tennessee } \\
\text { TN11 and 11TN }\end{array}$} \\
\hline & $\begin{array}{c}\text { Median } \\
\text { weekly } \\
\text { relative } \\
\text { difference }\end{array}$ & $\begin{array}{c}\text { Median } \\
\text { weekly } \\
\text { relative } \\
\text { percent } \\
\text { difference }\end{array}$ & $\begin{array}{c}\text { Annual } \\
\text { deposition } \\
\text { relative } \\
\text { percent } \\
\text { difference }\end{array}$ & $\begin{array}{c}\text { Range of } \\
\text { concentration } \\
\text { values }\end{array}$ & $\begin{array}{c}\text { Median } \\
\text { weekly } \\
\text { relative } \\
\text { difference }\end{array}$ & $\begin{array}{l}\text { Median } \\
\text { weekly } \\
\text { relative } \\
\text { percent } \\
\text { difference }\end{array}$ & $\begin{array}{c}\text { Annual } \\
\text { deposition } \\
\text { relative } \\
\text { percent } \\
\text { difference }\end{array}$ & $\begin{array}{c}\text { Range of } \\
\text { concentration } \\
\text { values }\end{array}$ \\
\hline Sodium $(\mathrm{mg} / \mathrm{L})$ & 0.003 & 21 & 15 & $0.004-0.172$ & 0.002 & 16 & 2.6 & $0.005-0.234$ \\
\hline Potassium (mg/L) & 0.010 & 28 & 21 & $0.007-0.185$ & 0.002 & 5 & 86 & $0.003-0.219$ \\
\hline Ammonium (mg/L) & 0.082 & 9 & 11 & $0.428-3.006$ & 0.010 & 9 & 6.2 & $0.018-0.486$ \\
\hline Chloride (mg/L) & 0.007 & 13 & 14 & $0.016-0.195$ & 0.005 & 7 & 6.2 & $0.013-0.348$ \\
\hline Nitrate $(\mathrm{mg} / \mathrm{L})$ & 0.164 & 16 & 18 & $0.456-3.056$ & 0.033 & 8 & 8.1 & $0.110-1.598$ \\
\hline Sulfate (mg/L) & 0.046 & 11 & 15 & $0.272-2.023$ & 0.024 & 7 & 7.6 & $0.111-1.914$ \\
\hline
\end{tabular}

The median weekly sample-volume difference was $-13 \mathrm{~mL}$ for the high-altitude $\mathrm{CO} 02$ and $02 \mathrm{CO}$ colocated sites where high winds commonly scour collected snow from the collector buckets. The collectors at $\mathrm{CO} 02$ and $02 \mathrm{CO}$ were installed inside wind fences to enhance retention of precipitation catch. The CO02 collector is not oriented with the wet bucket to the west as is standard NADP protocol. Instead, the CO02 wet bucket is oriented to the southwest. The $02 \mathrm{CO}$ collector was properly oriented to the west. This slight difference in collector orientation might have caused catch-efficiency differences between the two collectors that are unrelated to collector operation and function. This might also explain the larger relative percent differences in annual deposition for the CO02 and $02 \mathrm{CO}$ site compared to the other three colocated sampler study locations (tables 7 and 8). However, the $\mathrm{CO} 02$ site was selected for a colocated study because of its extreme winter weather conditions. Some portion of the measured differences could be due to high-speed wind conditions that affect the two instruments differently because of their east-west (02CO) versus north-south (CO02) orientations. 
Hydrogen-ion median weekly concentration differences ranged from -24 to +8.4 percent for the 2013-14 study period. The N-CON collector's base cation (calcium and magnesium) concentrations were also higher, which can buffer some of the hydrogen ion in the samples. As shown in previous studies and in this study, median weekly relative concentration differences ranged widely by analyte and by location (tables 7 and 8), which suggests that the use of both N-CON and ACM collectors to obtain chemical wet-deposition records imparts site- and analyte-specific effects on trends (Wetherbee and others, 2013a, 2014). The 2013-14 results indicate that trends in weekly wet-deposition concentrations could shift positively from +5 to +33 percent for cations and +7 to +24 percent for anions (tables 7 and 8). These results are consistent with those of previous colocated ACM and N-CON studies (Wetherbee and others, 2009, 2010, 2013a, 2014).

\section{Annual Deposition Values}

Annual deposition values were greater for N-CON collectors than for ACM collectors except for hydrogen-ion deposition at $\mathrm{CO} 00$ and $00 \mathrm{CO}, \mathrm{KS} 32$ and $32 \mathrm{KS}$, and TN11 and $11 \mathrm{TN}$ and sodium at $\mathrm{CO} 02$ and $02 \mathrm{CO}$ (tables 7 and 8). Annual deposition percent differences relative to the ACM collector varied widely by analyte. Annual deposition percent differences ranged from -14 to +102 percent for calcium, magnesium, sodium, and potassium; from +6.2 to +51 percent for ammonium; from +8.1 to +61 percent for nitrate; from +3.8 to +71 percent for chloride, nitrate and sulfate; and from -24 to +15 percent for hydrogen-ion concentrations.

\section{Precipitation-Gage Comparisons}

Daily precipitation-depth data for colocated precipitation gages were screened to eliminate days for which both gages measured zero depth. Results for comparison of precipitationdepth data for colocated ETI Noah IV precipitation gages at sites CO13 and 13CO, CO98 and CO89, and TN11 and 11TN are shown in figure $4 A$, and results for colocated OTT Pluvio-2 gages at sites $\mathrm{CO} 00$ and $00 \mathrm{CO}$ and $\mathrm{KS} 32$ and $32 \mathrm{KS}$ are shown in figure $4 B$. Daily precipitation-depth data for original and colocated sites were plotted against each other with reference to a 1:1 line. Median absolute percent differences for weekly summed data ranged from 0 to 3.7 percent for all colocated precipitation gages. Absolute differences for total annual precipitation depths ranged from 0.05 to 5.6 percent. Colocated OTT Pluvio-2 gages exhibited slightly higher median absolute percent differences and annual absolute differences than observed for the colocated ETI Noah IV gages. The variability between the colocated gages was small and comparable to variability observed in previous colocated studies (Wetherbee and others, 2005b).

\section{Mercury Deposition Network Quality Assurance Programs}

The USGS operated a system blank program and an interlaboratory comparison program for the MDN during 2013-14. Protocols for the USGS BQS external QA programs for MDN are described in detail by Latysh and Wetherbee (2007). The MDN system blank program is similar to the NTN field audit program, whereby the effects of onsite, environmental exposure, handling, and shipping on sample contamination are evaluated. The MDN interlaboratory comparison program quantified variability and bias of MDN analytical data provided by the Mercury Analytical Laboratory (HAL), which is Eurofins Frontier Global Sciences, Inc., in Bothell, Washington, for 2013-14.

\section{System Blank Program}

Approximately 20 to $26 \mathrm{MDN}$ site operators received quarterly system blank samples from USGS for processing and submission to HAL during the 2013-14 period. After a week without wet deposition at a site, site operators poured onehalf of the volume of their system blank solution through the sample train into the sample bottle. The solution that washed through the sample train is called the system blank sample, and the solution remaining in the original sample bottle is called the bottle sample. Both system blank and bottle samples were sent together to HAL for total mercury $(\mathrm{Hg})$ analysis. The HAL provided the system blank data to the USGS, and system-sample minus bottle-sample differences were calculated by the USGS.

Of the 190 system blank samples shipped to MDN sites during 2013-14, a total of 113 (61 percent) responses were received during 2013-14, plus 2 samples shipped in 2012 and processed during 2013. Data for system blank samples that were missing their corresponding bottle sample were eliminated from analysis, resulting in 96 paired system and bottle samples analyzed. Unopened bottle samples (22), some of which were shipped during 2012, were returned to the HAL and analyzed; these were considered trip blanks. The median trip-blank total $\mathrm{Hg}$ concentration was 0.033 nanograms per liter (ng/L).

\section{Network Maximum Contamination Levels for Mercury}

The NMCLs for total Hg were calculated from the system blank data using a 3-year moving window starting with the period 2004-06. The MDN NMCL for total Hg during 2012-14 was $1.87 \mathrm{ng} / \mathrm{L}$ (table 9). Thus, the maximum contamination in MDN samples during 2012-14 was not greater than $1.87 \mathrm{ng} / \mathrm{L}$ with 90 -percent confidence, and also, no more than 
A

C098/C089 ETI Noah IV, water years 2013-14

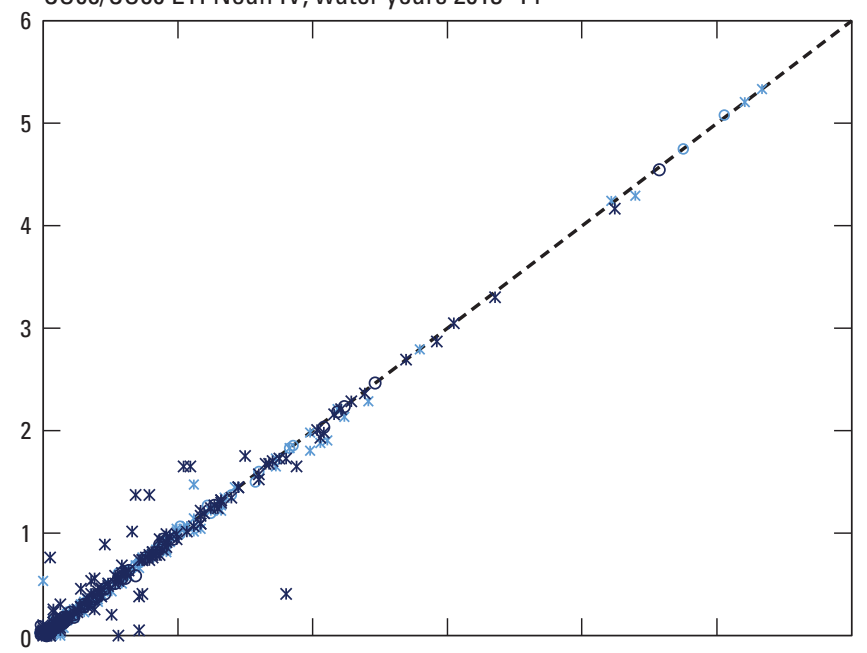

\begin{tabular}{cl} 
& \multicolumn{1}{c}{ EXPLANATION } \\
--- & 1:1 line \\
$\circ$ & Water year 2013-Rain \\
$*$ & Water year 2013-Snow/mixed/undefined \\
$\circ$ & Water year 2014—Rain \\
$*$ & Water year 2014—Snow/mixed/undefined
\end{tabular}

Median weekly absolute difference: 0 centimeter Median weekly absolute percent difference: $2.9 \%$

Annual absolute differences: 1.0 (2013) and 0.08 (2014) centimeter

Annual absolute percent differences: 0.8 (2013)

and $0.05 \%$ (2014)

Correlation coefficient: 0.989

C013/13CO ETI Noah IV, water year 2013

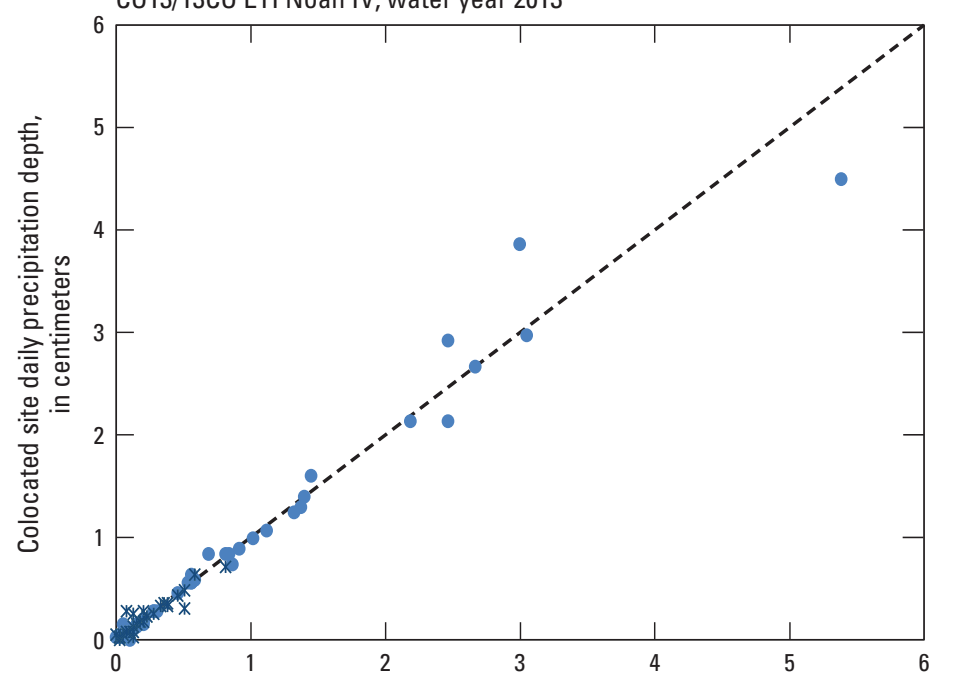

- - - 1:1 line

EXPLANATION

- Rain

* Snow/mixed/undefined

Median weekly absolute difference: 0.0 centimeter Median weekly absolute percent difference: $0.0 \%$ Annual absolute difference: 0.38 centimeter Annual absolute percent difference: $0.8 \%$ Correlation coefficient: 0.981

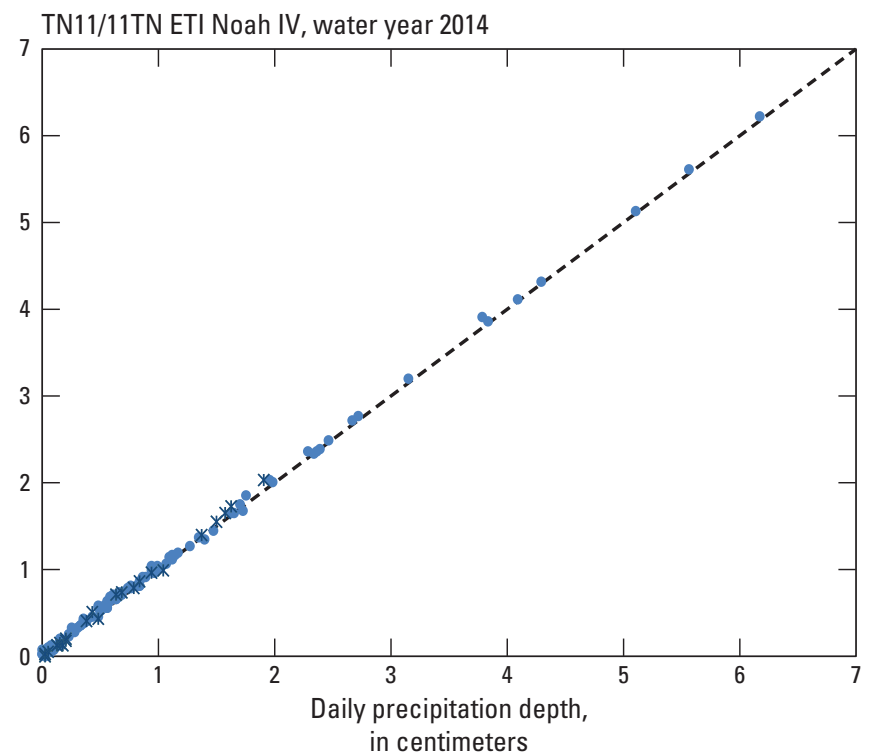

\section{EXPLANATION}

$--\quad$ 1:1 line

- Rain

* Snow/mixed/undefined

Annual absolute difference: 3.53 centimeter Annual absolute percent difference: $2.7 \%$

Median weekly absolute difference: 0.02 centimeter Median weekly absolute percent difference: $3.7 \%$

Correlation coefficient: 0.999

Figure 4. Daily precipitation depths and calculated median absolute percent differences for $(A)$ colocated ETI Noah IV precipitation gages, sites C013 and 13C0, C098 and C089, and TN11 and 11TN and (B) colocated 0TT Pluvio-2 precipitation gages, sites $\mathrm{CO} 00$ and $00 \mathrm{CO}$ and KS32 and 32KS, water years 2013-14. \%, percent. 


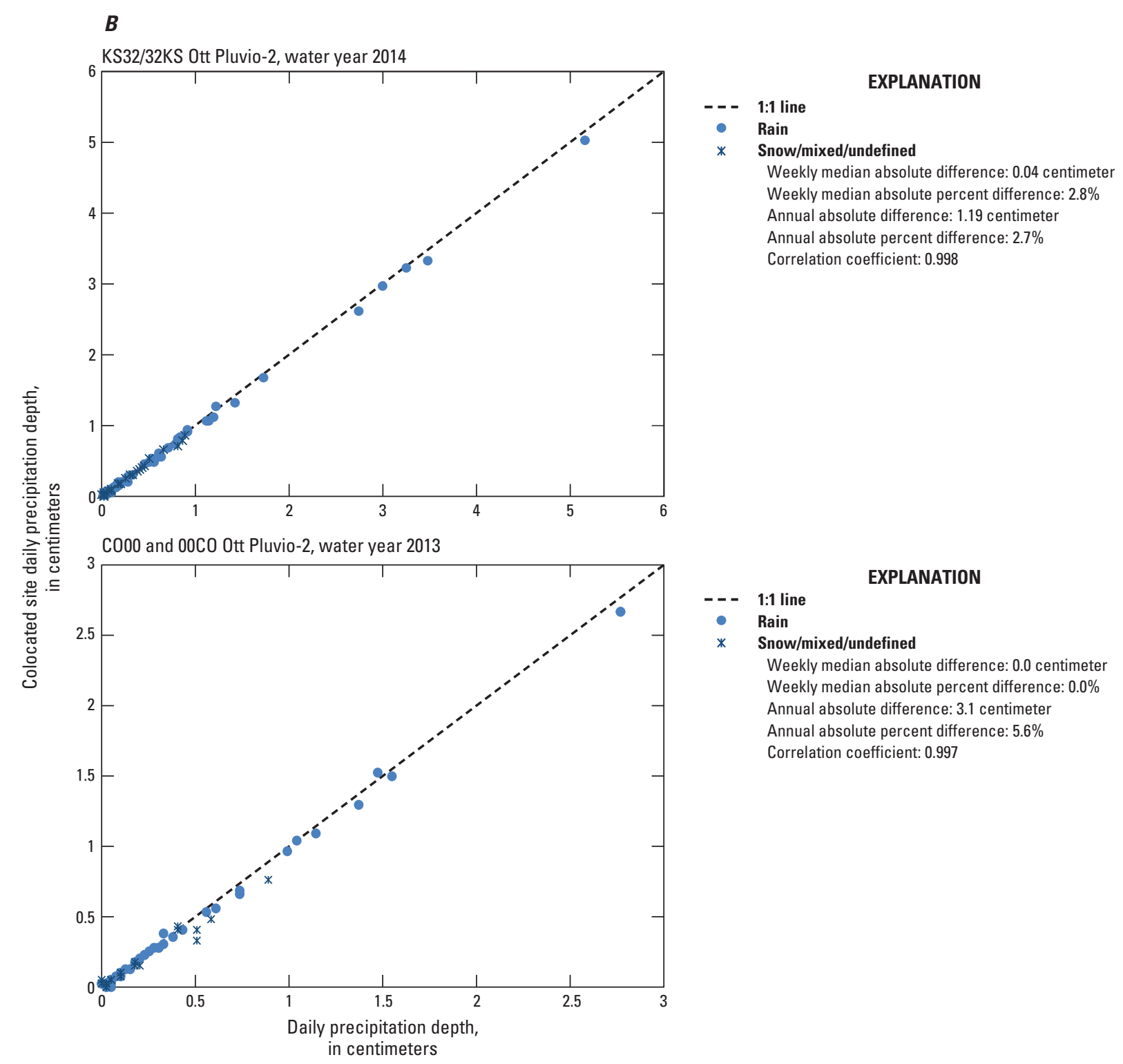

Figure 4. Daily precipitation depths and calculated median absolute percent differences for $(A)$ colocated ETI Noah IV precipitation gages, sites $\mathrm{CO} 13$ and 13CO, CO98 and C089, and TN11 and 11TN and (B) colocated 0TT Pluvio-2 precipitation gages, sites CO00 and 00CO and KS32 and 32KS, water years 2013-14. \%, percent.-Continued

10 percent of the MDN samples had contamination concentrations exceeding $1.87 \mathrm{ng} / \mathrm{L}$ with 90 -percent confidence. This concentration is approximately equal to the third percentile of all MDN weekly Hg concentrations (Sybil Anderson, Illinois State Water Survey, written commun, 2015). Therefore, the lowest 3 percent of all MDN total $\mathrm{Hg}$ concentrations could be entirely from contamination.

\section{Mass of Mercury Contamination}

The mass of $\mathrm{Hg}$ contamination in each system blank sample was calculated as follows:

$\mathrm{Hg}$ contamination $($ nanograms $)=$ $\left(\left[\mathrm{Hg}_{S B}\right] \times\right.$ Volume $\left._{S B}\right)-\left(\left[\mathrm{Hg}_{B o t}\right] \times\right.$ Volume $\left._{B o t}\right)$, where

$$
\begin{gathered}
{\left[\mathrm{Hg}_{S B}\right] \quad \text { is the total Hg concentration in system blank }} \\
\text { sample, in nanograms per liter, }
\end{gathered}
$$

Volume $_{S B}$ is the volume of system blank sample, in liters,

$\left[\mathrm{Hg}_{B o t}\right]$ is the total $\mathrm{Hg}$ concentration in the bottle sample, in nanograms per liter, and

Volume $_{B o t}$ is the volume of the bottle sample, in liters.

Next, the UCLs of the percentiles of the system-minus-bottle sample Hg mass differences were calculated. From the analytical results, the maximum estimated contaminant mass per sample increased from $0.26 \mathrm{ng} \mathrm{Hg}$ per sample during 2010-12 to $0.47 \mathrm{ng} \mathrm{Hg}$ during $2011-13$ to $0.54 \mathrm{ng} \mathrm{Hg}$ per sample during 2012-14 (table 9). 
Table 9. Three-year moving network maximum contamination levels and 90-percent upper confidence limits on 50th, 75th, and 90th percentiles of mercury contamination mass in system blank samples, 2004-14.

[\%, percent; UCL, upper confidence limit; Hg, total mercury; ng Hg, nanogram of mercury; ng $\mathrm{Hg} / \mathrm{L}$, nanogram of mercury per liter]

\begin{tabular}{|c|c|c|c|c|}
\hline \multirow[t]{3}{*}{$\begin{array}{l}\text { 3-year } \\
\text { period }\end{array}$} & \multirow{3}{*}{$\begin{array}{c}\text { Network } \\
\text { maximum } \\
\text { contamination } \\
\text { level } \\
\text { (ng Hg/L) }\end{array}$} & \multirow{2}{*}{\multicolumn{3}{|c|}{$\begin{array}{c}\text { 90\% UCLs on percentiles } \\
\text { of Hg contamination mass in system } \\
\text { blank samples } \\
\text { (ng Hg) } \\
\text { Percentiles }\end{array}$}} \\
\hline & & & & \\
\hline & & 50th & 75th & 290th \\
\hline 2004-06 & 041 & 0.005 & 0.095 & 0.095 \\
\hline $2005-07$ & $1.00 /$ & 0.018 & 0.067 & 0.136 \\
\hline 2006-08 & 2.170 & 0.040 & 0.100 & 0.233 \\
\hline 2007-09 & 3.476 & 0.060 & 0.120 & 0.325 \\
\hline $2008-10$ & 4.260 & 0.070 & 0.152 & 0.325 \\
\hline 2009-11 & 1.588 & 0.068 & 0.140 & 0.285 \\
\hline 2010-12 & 1.771 & 0.065 & 0.120 & 0.260 \\
\hline 2011-13 & 1.871 & 0.052 & 0.097 & 0.470 \\
\hline $2012-14$ & 1.871 & 0.045 & 0.095 & 0.536 \\
\hline
\end{tabular}

${ }^{1}$ Defined as the 90-percent UCL on 90th percentile of system-blank $\mathrm{Hg}$ contamination concentrations.

${ }^{2}$ Defined as the maximum contamination mass per sample.

\section{Mercury Deposition Network Interlaboratory Comparison Program}

The objective of the MDN interlaboratory comparison program is to estimate variability and bias of HAL analytical data in comparison with results from analytical laboratories supporting various monitoring networks, not accounting for the different onsite protocols used by different monitoring networks. Eleven laboratories participated in the program during the study period.

1. HAL at Eurofins Frontier Global Sciences, Inc., in Bothell, Wash;

2. Chinese Academy of Sciences, Institute of Geochemistry (CASIG), in Guiyang, People's Republic of China;

3. Department of Atmospheric Science, National Central University (DASNCU), in Jhong-Li District, Taoyuan City, Taiwan;

4. Flett Research, Ltd. (FRL), in Winnipeg, Manitoba, Canada;

5. Germany air pollution (quality) monitoring network (GAPMN) at the Federal Environment Agency

[Umweltbundesamt] in Langen, Germany

(http://www.umweltbundesamt.de/en/topics/air/ measuringobservingmonitoring/air-monitoring-networks);

6. Swedish Environmental Institute (IVL) in Goteborg, Sweden;

7. Jozef Stefan International Postgraduate School (JSIPS) in Ljubljana, Slovenia;

8. Quebec Laboratory for Environmental Testing (LEEQ or QLET) in Montreal, Quebec, Canada;
9. North Shore Analytical, Inc. (NSA), in Duluth, Minnesota;

10. Flemish Institute for Technological Research (VITO) in Mol, Belgium; and

11. USGS Wisconsin Mercury Laboratory (WML) in Middleton, Wisconsin.

All laboratories analyzed for low-level $\mathrm{Hg}$ in water using atomic fluorescence spectrometry methods similar to U.S. Environmental Protection Agency (EPA) Method 1631 (U.S. Environmental Protection Agency, 2002). The VITO laboratory dropped out of the program in January 2014.

During the study period, the CASIG, DASNCU, GAPMN, JSIPS, and IVL participants were also involved in various roles for the Global Mercury Observation System (GMOS), a long-term global mercury monitoring study (http://www.gmos.eu/, accessed September 10, 2014). Three additional GMOS laboratories in France, Italy, and South Africa declined to participate in this program. GMOS monitoring ended in 2015, at the time of this writing.

During 2013-14, each participating laboratory received two samples per month consisting of 1-percent (volume:volume) hydrochloric acid blanks and mercuric nitrate spiked at four different concentrations in a 1-percent hydrochloric acid matrix, identified as MP1, MP2, MP3, and MP4. The laboratories were instructed to analyze their samples as soon as they received them to promote accurate time representation of the data. All samples were single-blind samples, where the chemical analyst knew that the sample was a quality control sample but did not know the total $\mathrm{Hg}$ concentrations of the samples. The medians of all of the concentration values obtained from the participating laboratories were considered to be MPVs, which are listed in table 10.

Table 10. Most probable values for solutions used during 2013-14 for the Mercury Deposition Network interlaboratory comparison program.

[Hg, total mercury; MPV, most probable value; ng/L, nanogram per liter; $\%$, percent; $\mathrm{HCl}$, hydrochloric acid; Blank, mercury-free de-ionized water with $1 \% \mathrm{HCl}$ by volume; MP1-MP4, mercuric nitrate standard diluted to target concentrations in $1 \% \mathrm{HCl}$; Blank MPVs estimated by Kaplan-Meier method in R-NADA package because of large number of censored values]

\begin{tabular}{|c|c|}
\hline Solution identifier & $\begin{array}{c}\text { Total } \\
\text { Hg concentration } \\
\text { MPV } \\
\text { (ng/L) }\end{array}$ \\
\hline \multicolumn{2}{|c|}{2013} \\
\hline $1 \% \mathrm{HCl}$ BLANK & 0.04 \\
\hline MP1 & 5.763 \\
\hline MP2 & 8.430 \\
\hline MP3 & 14.10 \\
\hline MP4 & 20.20 \\
\hline \multicolumn{2}{|c|}{2014} \\
\hline $1 \% \mathrm{HCl}$ BLANK & 0.02 \\
\hline MP1 & 5.860 \\
\hline MP2 & 8.895 \\
\hline MP3 & 14.70 \\
\hline MP4 & 20.90 \\
\hline
\end{tabular}




\section{Control Charts}

Total $\mathrm{Hg}$ analysis data submitted by each laboratory were compared to MPVs for each solution. Differences between reported results and MPVs were plotted on annual control charts available on the PCQA Web site at https://bqs.usgs.gov/PCQA/ Interlaboratory_Comparison/graphOutput.php?page=start (accessed November 6, 2015). Control charts included warning limits placed at $\pm 2 f$-psig and control limits at $\pm 3 f$-psig from the zero difference line during the study period. Values outside the control limits represent periods when a laboratory's analyses might have been outside of statistical control.

The HAL's control chart for the 2013-14 interlaboratory comparison analyses shows that all results were within statistical control ( $\pm 3 f$-psig) with two analyses outside the negative warning limit ( $-2 f$-psig) during 2013 (fig. 5). A trend in negative bias of approximate $-1 \mathrm{ng} / \mathrm{L}$ in early 2013 was observed, followed by no bias to a slightly negative bias situation during the winter of 2013-14 and an approximately $+1-n g / L$ bias from late 2014 to the end of the study period. These temporal trends describe a +2-ng/L shift in bias between 2013 and 2014, which might be important for interpretation of trends in the monitoring data.

\section{Interlaboratory Variability and Bias}

Each laboratory's results for variability and bias are summarized in table 11. Methods for evaluation of the interlaboratory variability and bias for the MDN interlaboratory comparison program are analogous to those for the NTN interlaboratory comparison program. The $f$-psig ratio was computed as shown in equation 6 and expressed as a percentage for each laboratory, whereby an $f$-psig ratio larger than 100 percent indicates that results provided by a laboratory exhibited higher variability than the overall variability among the participating laboratories; a ratio smaller than 100 percent indicates less variability than overall.

Annual overall $f$-psig values were $0.72 \mathrm{ng} / \mathrm{L}$ and $0.52 \mathrm{ng} / \mathrm{L}$ for 2013 and 2014, respectively, for the concentration ranges indicated by the MPVs in table 10. Results in table 11 indicate that HAL total Hg analyses were characterized by less variability than overall in 2013 with an $f$-psig ratio of 55 percent, but during 2014, the HAL's results were more variable than overall with an $f$-psig ratio of 136 percent (for example, 36 percent more variable than overall). Nonetheless, the HAL's performance was similar to that of FRL and NSA during 2013, with a small median difference that was not statistically significant from zero and low variability $(f$-psig ratio $<100$ percent) (table 11$)$. The HAL's performance was most similar to JSIPS and NSA during 2014, with an insignificant, small median difference and slightly more variability than overall $(f$-psig ratio of 136 percent).

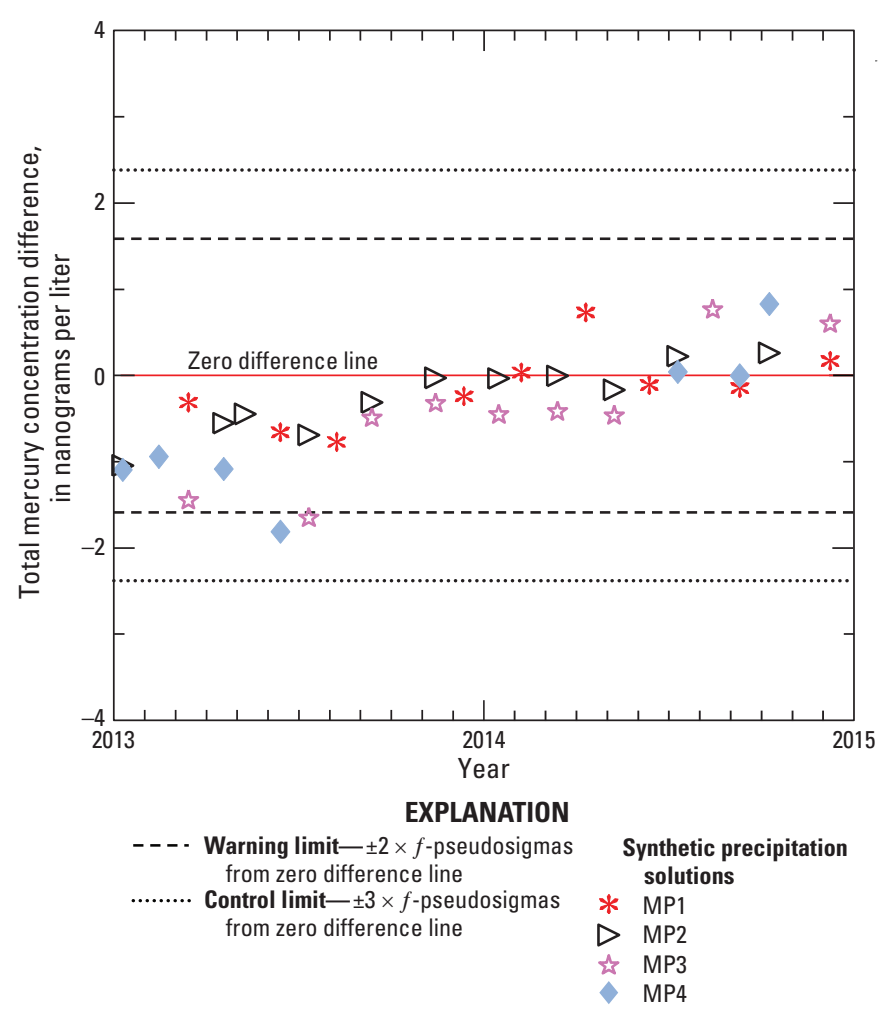

Figure 5. Differences between total mercury concentrations reported by the HAL and the median concentration values for all participating laboratories in the interlaboratory comparison program for the Mercury Deposition Network, 2013-14.

The arithmetic signs of the median differences indicate whether reported total mercury analysis results were positively or negatively biased. Interlaboratory bias was evaluated for statistical significance using the sign test for location of a median (Kanji, 2006; Wetherbee and others, 2013a). The -0.17-ng/L bias observed for HAL during 2013 and the +0.12 -ng/L bias observed for HAL during 2014 were not significantly $(\alpha=0.05)$ different from a median of zero. The first percentile of all weekly MDN total $\mathrm{Hg}$ concentrations is $1.27 \mathrm{ng} / \mathrm{L}$; therefore, the annual bias estimates for HAL data are negligible compared to environmental concentrations determined during 2013 and 2014 (Sybil Anderson, Illinois State Water Survey, written commun., 2015).

\section{Results for Mercury Deposition Network Interlaboratory Comparison Program Blanks}

Interlaboratory comparison results for 2013-14 blank samples are shown in table 12. Minimum reporting levels (MRLs) vary between laboratories and were less than or equal to $0.58 \mathrm{ng} / \mathrm{L}$ during 2013-14. Median total Hg concentrations obtained for interlaboratory comparison program blanks were $0.04 \mathrm{ng} / \mathrm{L}$, with 40 percent of the results less than the MRLs for 2013 and $0.02 \mathrm{ng} / \mathrm{L}$ with 80 percent of results less than the MRLs for 2014. Laboratories with lower MRLs reported more 
Table 11. Differences between reported concentrations and most probable values for total mercury determinations, Mercury Deposition Network interlaboratory comparison program, 2013-14.

$[\mathrm{ng} / \mathrm{L}$, nanograms per liter; overall $f$-psig, $f$-pseudosigma for all participating laboratories; median diff., median of differences between each laboratory's individual results and the most probable values for each solution; sign test $p$-value, probability of rejecting the null hypothesis: "The true median of the differences between laboratory results and the most probable value is zero," when true; $f$-psig ratio, ratio of each individual laboratory's $f$-pseudosigma to the overall $f$-pseudosigma, in percent; \%, percent; sign test $p$-value, probability of rejecting the null hypothesis: "The true median of the differences between laboratory results and the most probable value is zero," when true; HAL, Mercury Analytical Laboratory at Eurofins Frontier Global Sciences, Inc.; CASIG, Chinese Academy of Sciences, Institute of Geochemistry; DASNCU, Department of Atmospheric Sciences, National Central University; FRL, Flett Research, Ltd.; GAPMN, Germany air pollution (quality) monitoring network at Federal Environment Agency [Umweltbundesamt]; IVL, Swedish Environmental Research Institute; JSIPS, Jozef Stefan International Postgraduate School; LEEQ, Quebec Laboratory of Environmental Testing, also known as QLET; NSA, North Shore Analytical, Inc.; VITO, Flemish Institute for Technological Research; WML, U.S. Geological Survey Wisconsin Mercury Laboratory; n.d., no data; <, less than; statistical warning limits are +2 overall $f$-psig, statistical control limits are +3 overall $f$-psig]

\begin{tabular}{|c|c|c|c|c|c|}
\hline Year & $\begin{array}{l}\text { Overall } \\
f \text {-psig } \\
\text { (ng/L) }\end{array}$ & $\begin{array}{l}\text { Median } \\
\text { diff. } \\
\text { (ng/L) }\end{array}$ & $\begin{array}{c}\text { Sign } \\
\text { test } \\
p \text {-value }\end{array}$ & $\begin{array}{c}f \text {-psig } \\
\text { ratio } \\
(\%)\end{array}$ & $\begin{array}{c}\text { Number of values } \\
\text { outside limits } \\
\text { (warning/control) }\end{array}$ \\
\hline \multicolumn{6}{|c|}{ Laboratory } \\
\hline 2013 & 0.716 & -0.169 & 0.238 & 55 & $2 / 0$ \\
\hline 2014 & 0.519 & 0.120 & 0.238 & 136 & $0 / 0$ \\
\hline \multicolumn{6}{|c|}{ CASIG } \\
\hline \multicolumn{6}{|c|}{ DASNCU } \\
\hline 2013 & 0.716 & -1.565 & $<0.001$ & 192 & $3 / 5$ \\
\hline 2014 & 0.519 & -1.858 & $<0.001$ & 170 & $6 / 9$ \\
\hline \multicolumn{6}{|c|}{ FRL } \\
\hline 2013 & 0.716 & 0.088 & 0.263 & 28 & $0 / 0$ \\
\hline 2014 & 0.519 & -0.270 & 0.001 & 55 & $0 / 0$ \\
\hline 2013 & 0.716 & 0.327 & 0.001 & 38 & $0 / 0$ \\
\hline 2014 & 0.519 & 0.060 & 0.359 & 42 & $0 / 0$ \\
\hline \multicolumn{6}{|c|}{ JSIPS } \\
\hline 2013 & 0.716 & -0.168 & 0.481 & 135 & $1 / 2$ \\
\hline 2014 & 0.519 & -0.010 & 1.000 & 143 & $2 / 2$ \\
\hline \multicolumn{6}{|c|}{ LEEO } \\
\hline 2013 & 0.716 & 1.444 & 0.001 & 119 & $6 / 2$ \\
\hline 2014 & 0.519 & 0.658 & $<0.001$ & 135 & $3 / 2$ \\
\hline \multicolumn{6}{|c|}{ NSA } \\
\hline 2013 & 0.716 & -0.106 & 0.814 & 83 & $0 / 0$ \\
\hline 2014 & 0.519 & -0.028 & 0.503 & 101 & $0 / 0$ \\
\hline \multicolumn{6}{|c|}{${ }^{1}$ VITO } \\
\hline
\end{tabular}

${ }^{1}$ VITO left the program in January 2014.

values above their MRLs for the blank samples. Using the Kaplan-Meier method from the NADA package in R statistical software (R-NADA), maximum detected Hg concentrations in the blank samples were estimated at $0.68 \mathrm{ng} / \mathrm{L}$ for 2013 and $0.25 \mathrm{ng} / \mathrm{L}$ for 2014 (R Core Team, 2013). These concentrations were lower than the first percentile of all MDN monitoring data and thus did not indicate bias due to sample cross-contamination in the laboratory (Sybil Anderson, Illinois State Water Survey, written commun., 2015). The HAL blank results were similar to those from the other participating laboratories.
The HAL results for blanks indicate that laboratory $\mathrm{Hg}$ contamination during the study period was low. Therefore, most $\mathrm{Hg}$ contamination in MDN samples, which was estimated using the system blanks, was likely introduced in the field. Wetherbee and Rhodes (2013b) showed how sample evaporation and associated $\mathrm{Hg}$ loss from MDN samples can occur, especially for the modified ACM MDN collectors. Cross-contamination between samples could result from evaporated samples condensing on the collectors' uncleaned lid pads, which could also help explain the increases in sample contamination observed in the system blanks. 
Table 12. Number of total mercury determinations greater than the method detection limits by participating laboratory for blank samples, Mercury Deposition Network interlaboratory comparison program, 2013-14.

[Four determinations per year per laboratory; HAL, Mercury Analytical Laboratory at Eurofins Frontier Global Sciences, Inc.; CASIG, Chinese Academy of Sciences, Institute of Geochemistry; DASNCU, Department of Atmospheric Sciences, National Central University; FRL, Flett Research, Ltd.; GAPMN, Germany air pollution (quality) monitoring network at Federal Environment Agency [Umweltbundesamt]; IVL, Swedish Environmental Research Institute; JSIPS, Jozef Stefan International Postgraduate School; LEEQ, Quebec Laboratory of Environmental Testing, also known as QLET; NSA, North Shore Analytical, Inc.; VITO, Flemish Institute for Technological Research; WML, U.S. Geological Survey Wisconsin Mercury Laboratory; ng/L, nanogram per liter; n.d., no data]

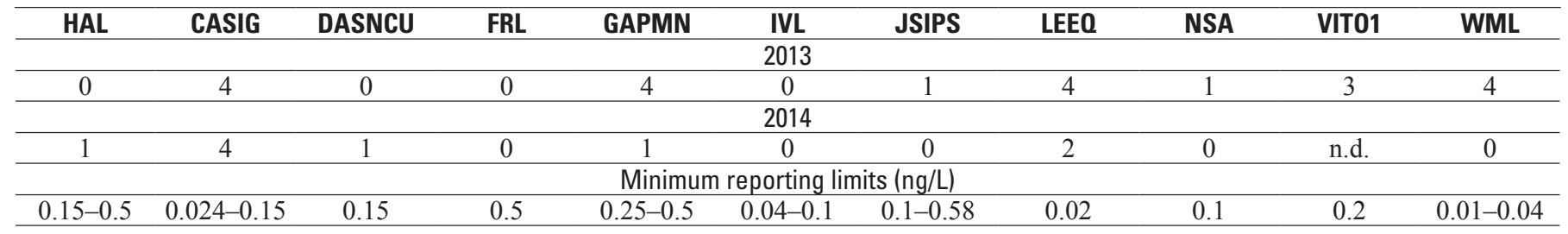

${ }^{1}$ VITO left the program in January 2014.

\section{Summary}

The U.S. Geological Survey (USGS) used 3 programs to provide external quality assurance monitoring for the National Atmospheric Deposition Program's (NADP) National Trends Network (NTN) and 2 programs to provide external quality assurance monitoring for the NADP Mercury Deposition Network (MDN) during 2013-14. The field audit program assessed the effects of onsite exposure, sample handling, and shipping on the chemistry of NTN samples; the system blank program assessed the same effects for MDN samples. Two interlaboratory comparison programs assessed the bias and variability of the chemical analysis data from the Central Analytical Laboratory (CAL), Mercury Analytical Laboratory (HAL), and 17 other participating laboratories for NTN and MDN programs combined. A colocated sampler program was used to quantify (1) the variability of electronic recording precipitation gages and (2) potential shifts in NADP data resulting from the bias of new NTN sample collectors that use optical sensors.

\section{National Trends Network}

Field audit results for 2013-14 indicate that the 3-year moving network maximum contamination levels (NMCLs) for calcium, nitrate, and sulfate continued to increase during 2012-14. Sodium and chloride NMCLs decreased during 2012-14, while NMCLs for magnesium, potassium, ammonium, and hydrogen ion remained relatively constant. Ammonium and nitrate losses continued to be lower than previous years, possibly from disinfection of the reused sample buckets with hydrogen peroxide prior to washing with de-ionized water. Values for maxium analyte losses are less than or equal to the 2013 and 2014 method detection limits (MDLs), a pattern which indicated that analyte losses from NTN samples were negligible during the study period.

The NADP's Central Analytical Laboratory (CAL) and the AMEC Foster Wheeler (2014), formerly AMEC, Inc., (2013); Environment and Climate Change Canada (formerly Environment Canada in 2013-14) Science and Technology
Branch (ECST); and Carey Institute of Ecosystem Studies laboratories exhibited comparable, low overall variability among the participating laboratories during 2013-14. Absolute median differences between CAL's results and the most probable values (MPVs, medians) were less than or equal to CAL's MDLs except for chloride in 2013. The CAL's results for de-ionized water blanks included 1 detection for calcium and 1 detection for sulfate greater than the MDLs during 2014. No other analytes were detected at concentrations exceeding the MDLs for the other de-ionized water blanks analyzed by CAL.

Median absolute percent differences between weekly measured precipitation depths from electronically recording gages ranged from 0 to 3.7 percent. Annual absolute differences ranged from 0.05 to 5.6 percent, and the colocated OTT Pluvio-2 gages exhibited slightly higher differences than the colocated Environmental Technologies, Inc., Noah IV gages. Variability of collected data between the colocated gages was small compared to the range of analyte concentrations observed in NTN monitoring data.

Paired weekly N-CON Systems, Inc. (N-CON)-minusAerochem Metrics Model 301 (ACM) concentration differences were calculated to evaluate bias. Median weekly concentration differences were all positively signed except for hydrogen-ion concentration at 3 of the 4 colocated sampler study locations, which indicated that N-CON concentrations generally were higher than ACM concentrations. Paired sample volume measurements indicated a median weekly percent difference from -1.4 to +23 in the amounts of precipitation caught by the N-CON versus ACM collectors.

\section{Mercury Deposition Network}

The maximum contamination in MDN samples (NMCLs) during the 3-year intervals from 2011-13 and 2012-14 was not greater than $1.87 \mathrm{ng} / \mathrm{L}$ with 90 -percent confidence. This concentration was approximately equal to the third percentile of all MDN weekly $\mathrm{Hg}$ concentrations. The maximum contamination mass per sample increased from $0.26 \mathrm{ng} \mathrm{Hg}$ per sample during 2010-12 to $0.47 \mathrm{ng} \mathrm{Hg}$ during 2011-13 and again to $0.54 \mathrm{ng} \mathrm{Hg}$ per sample during 2012-14. 
The Mercury Analytical Laboratory (HAL) at Eurofins Frontier Global Sciences achieved analytical quality consistent with that of other historically high-performing laboratories in the interlaboratory comparison program for the MDN. The HAL produced total $\mathrm{Hg}$ concentration analyses with less variability than the other participating laboratories during 2013, but during 2014, the HAL's results were slightly more variable than overall.

A - 0.169-ng/L bias was observed for HAL total $\mathrm{Hg}$ concentrations during 2013 and a $+0.120-n g / L$ bias observed for HAL during 2014, but these differences were not statistically $(\alpha=0.05)$ significantly different from zero. The annual bias estimates for HAL data were less than the first percentile of all weekly MDN total $\mathrm{Hg}$ concentrations (1.27 ng/L). However, a control chart of HAL results showed a trend in analytical bias with an approximately $-1-\mathrm{ng} / \mathrm{L}$ bias in early 2013 , no bias to a slightly negative bias during the winter of 2013-14, and an approximately $+1-\mathrm{ng} / \mathrm{L}$ bias in late 2014 . These shifts in biases are important for the interpretation of trends in MDN total $\mathrm{Hg}$ wet-deposition data.

\section{References Cited}

Dossett, S.R., and Bowersox, V.C., 1999, National Trends Network site operation manual: Champaign, Ill., Illinois State Water Survey, National Atmospheric Deposition Program Manual 1999-01, 94 p., accessed December 27, 2007, at http://nadp.sws.uiuc.edu/lib/manuals/opman.pdf.

Gibbons, R.D., and Coleman, D.E., 2001, Statistical methods for detection and quantification of environmental contamination: New York, John Wiley \& Sons, p. 139-146.

Hahn, G.J., and Meeker, W.Q., 1991, Statistical intervals-A guide for practitioners: New York, John Wiley \& Sons, 392 p.

Helsel, D.R., 2012, Statistics for censored environmental data using Minitab and R (2d ed.): Hoboken, N.J., John Wiley \& Sons, p. 70-77.

Hoaglin, D.C., Mosteller, Frederick, and Tukey, J.W., 1983, Understanding robust and exploratory data analysis:

New York, John Wiley \& Sons, p. 38-41.

Kanji, G.K., 2006, 100 statistical tests (3d ed.): New Delhi, Sage Publications Ltd., 242 p.

Latysh, N.E., and Wetherbee, G.A., 2005, External quality assurance programs managed by the U.S. Geological Survey in support of the National Atmospheric Deposition Program/National Trends Network: U.S. Geological Survey Open-File Report 2005-1024, 66 p.

Latysh, N.E., and Wetherbee, G.A., 2007, External quality assurance programs managed by the U.S. Geological Survey in support of the National Atmospheric Deposition Program/Mercury Deposition Network: U.S. Geological Survey Open-File Report 2007-1170, 33 p.
Lynch, J.A., DeWalle, D.R., and Horner, Kevin, 1990, Project summary-Impact of NADP/NTN sampling protocols on winter storm estimates of wet deposition in central Pennsylvania: U.S. Environmental Protection Agency report EPA/600/S3-90/044, 8 p.

Morris, Kristi, Mast, Alisa, Clow, Dave, Wetherbee, Greg, Baron, Jill, Taipale, Curt, Blett, Tamara, Gay, David, and Heath, Jared, 2014, 2012 Monitoring and tracking wet nitrogen deposition at Rocky Mountain National Park: National Park Service, Natural Resource Report NPS/NRSS/ARD/ NR-2014/757, $24 \mathrm{p}$.

Mueller, D.K., and Titus, C.J., 2005, Quality of nutrient data from streams and ground water sampled during water years 1992-2001: U.S. Geological Survey Scientific Investigations Report 2005-5106, 27 p.

National Atmospheric Deposition Program, http://nadp.sws. uiuc.edu/, last accessed February 3, 2015.

National Atmospheric Deposition Program, 2015, 2014 Annual Summary, Illinois State Water Survey: UrbanaChampaign, Illinois, University of Illinois, Prairie Research Institute, 27 p. [Also available at http://nadp.sws.uiuc.edu/ lib/data/2014as.pdf.]

R Development Core Team (2013), R-A language and environment for statistical computing: Vienna, Austria, R Foundation for Statistical Computing, ISBN 3-900051-07-0, accessed January 11, 2016, at http://www.R-project.org/.

SAS Institute, Inc., 2001, SAS/STAT 9.2 user's guide: Cary, N.C., SAS Institute, Inc.

Tchobanoglous, George, and Schroeder, E.D., 1987, Water quality - Characteristics, modeling, modification: Reading, Mass., Addison-Wesley Publishing Company, Inc., p. 204-207.

U.S. Environmental Protection Agency, 2002, Method 1631, revision E-Mercury in water by oxidation, purge and trap, and cold vapor atomic fluorescence spectrometry: U.S. Environmental Protection Agency, Office of Water report EPA-821-R-02-019, 38 p., accessed May 6, 2014, at http://water.epa.gov/scitech/methods/cwa/metals/mercury/ upload/2007_07_10_methods_method_mercury_1631.pdf.

Wetherbee, G.A., Latysh, N.E., and Burke, K.P., 2005a, External quality assurance results for the National Atmospheric Deposition Program/National Trends Network, 2002-03: U.S. Geological Survey Scientific Investigations Report 2005-5061, 59 p.

Wetherbee, G.A., Latysh, N.E., and Gordon, J.D., 2005b, Spatial and temporal variability of the overall error of National Atmospheric Deposition Program measurements determined by the USGS co-located-sampler program, water years 1989-2001: Environmental Pollution, v. 135, p. 407-418. 
Wetherbee, G.A., Latysh, N.E., and Greene, S.M., 2006, External quality assurance results for the National Atmospheric Deposition Program/National Trends Network, 2004: U.S. Geological Survey Scientific Investigations Report 2006-5067, 52 p.

Wetherbee, G.A., Latysh, N.E., Greene, S.M., and Chesney, T.A., 2009, U.S. Geological Survey external qualityassurance program results reported to the National Atmospheric Deposition Program/National Trends Network and Mercury Deposition Network for 2005-06: Champaign, Ill., National Atmospheric Deposition Program Quality Assurance Report 2009-01, Illinois State Water Survey Data/Case Study 2009-01, 54 p.

Wetherbee, G.A., Latysh, N.E., Greene, S.M., and Chesney, T.A., 2010, U.S. Geological Survey external qualityassurance project report to the National Atmospheric Deposition Program/National Trends Network and Mercury Deposition Network, 2007-08: Champaign, Ill., National Atmospheric Deposition Program Quality Assurance Report 2010-01 and Illinois State Water Survey Miscellaneous Publication 190, 82 p.
Wetherbee, G.A., Martin, R.A., Rhodes, M.F., and Chesney, T.A., 2013, External quality-assurance project report for the National Atmospheric Deposition Program/National Trends Network and Mercury Deposition Network for 2009-2010: U.S. Geological Survey Scientific Investigations Report 2013-5147, 53 p.

Wetherbee, G.A., and Rhodes, M.F., 2013, Effects of equipment performance on data quality from the National Atmospheric Deposition Program/National Trends Network and the Mercury Deposition Network: U.S. Geological Survey Open-File Report 2013-1031, 53 p.

Wetherbee, G.A., and Martin, R.A., 2014, U.S. Geological Survey external quality-assurance project report for the National Atmospheric Deposition Program/National Trends Network and Mercury Deposition Network, 2011-12: National Atmospheric Deposition Program Quality Assurance Report 2014-01 and Illinois State Water Survey Miscellaneous Publication 202, 62 p.

Wilde, F.D., Radtke, D.B., Gibs, J., and Iwatsubo, R.T., eds., variously dated, National field manual for the collection of water-quality data-Processing of water samples (ver. 2.2): U.S. Geological Survey Techniques of Water-Resources Investigations, book 9, chap. A5, p. 90.

Publishing support provided by the Denver Publishing Service Center

For more information concerning this publication, contact: Chief, USGS Branch of Quality Systems

Box 25046, Mail Stop 401

Denver, CO 80225

(303) 236-1835

Or visit the Branch of Quality Systems Web site at http://bqs.usgs.gov/

This publication is available online at http://dx.doi.org/10.3133/sir20165069 

